\title{
Greek High Culture in Hellenistic and Early Imperial Bithynia
}

\section{Towards a Prosopography of Practitioners of Greek Culture in Bithynia Down to the Middle of the Third Century AD}

\author{
Ewen Bowie \\ Corpus Christi College, Oxford, United Kingdom \\ ewen.bowie@ccc.ox.ac.uk
}

Received February 2021 | Accepted April 2021

\begin{abstract}
The article attempts to set out evidence for various forms of Greek high culture in Bithynia from the fifth century $\mathrm{BC}$ to the middle of the third century $\mathrm{AD}$, taking as a cut-off point the tetrarchic period in which Diocletian's choice of Nicomedia as a capital had a marked impact on its and other Bithynian cities' cultural life. The preliminary prosopography lists representatives of Greek culture by city, subdividing into the categories doctor, grammaticus, historian, philosopher, poet, rhetor or sophist, and scholar (with a sprinkling of other performers). Only Nicaea, with 30 names, makes a strong and persistent showing; of other cities only Nicomedia musters more than 10 names, though Prusa and Prusias ad mare produce several doctors. Prusias ad Hypium, by contrast, can boast only a single philosopher, perhaps a rhetor who moved to Nicaea, and a visiting tragic performer.
\end{abstract}

\section{Keywords}

city - hellenisation - medicine - philosophy - poet - rhetoric

\section{Introduction}

Bithynia had no Greek settlements before the 'colonising' movement of the eighth and seventh centuries BC. Even that established only a few cities - the 
à $\pi$ oxial ('colonies') of Astacus (712/711 BC) and Chalcedon (685 BC, modern Kadıköy), Megarian foundations; Cius, a Milesian foundation; and Myrleia, originally founded by Colophonians as Brylleion. Olbia may be added: its location, not certainly identified, was in the eastern part of the Gulf of Nicomedia. ${ }^{1}$

The number of Greek cities grew with the creation of a kingdom of Bithynia. Its second king, Nicomedes I (c. 279-c. 255 BC), replaced Astacus, which had been taken by Lysimachus, with his adjacent foundation, Nicomedia, which he made his capital. In the East he founded Bithynion, apparently de novo. He also annexed the city at the eastern end of Lake Ascanius: this had started life as Antigoneia when founded by Philip's son Antigonus in 311 BC; then, in 301 BC, it became Nicaea, named after Lysimachus' wife. ${ }^{2}$

At the end of the third century Bithynia's expansion by Prusias I (c. 230$182 \mathrm{BC}$ ) added the coastal cities of Cius and Myrleia to the kingdom. Cius became Prusias ad mare; ${ }^{3}$ and either then or later, under Nicomedes II (149-127 BC), Myrleia became Apamea. Prusias also acquired Heracleia Pontica's colony Cierus, which became Prusias ad Hypium, ${ }^{4}$ took Tieium, and founded de novo Prusa ad Olympum. ${ }^{5}$ In the first century вС, Caesar founded colonia Iulia Concordia (later colonia Iulia Concordia Augusta) on Apamean territory, but apparently the Greek city continued to exist.

These cities old and new were major vehicles of hellenisation, seemingly a conscious policy of all the Bithynian kings. One interesting case involves the myth of Hylas. It is no accident that in the mid-third century вс Apollonius of Rhodes (1.1207-1357) and Theocritus (Idyll 13), and in the mid-second century вс Nicander (cf. Ant.Lib. no. 26), set versions of the Argonaut Hylas' abduction by a nymph or nymphs in the back-country of Cius. This poetic activity reflects

1 Ptol. Geog. 5.1.3, though Plin. Nat. 5.148 takes Olbia to be an earlier name of Nicaea. That Olbia is another name for Astacus is possible but beyond proof, see K. Strobel in Brill's New Pauly s.n. 'Olbia [5]'. For these and other Bithynian cities' locations see Map 1.

2 Str. $12 \cdot 4 \cdot 7 \cdot 565 \mathrm{C}$.

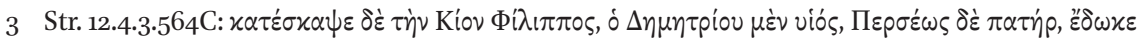

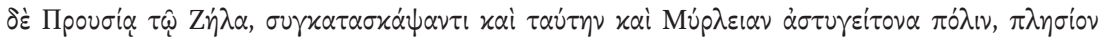

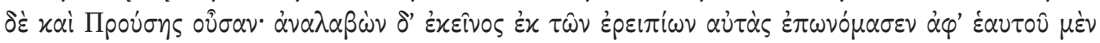

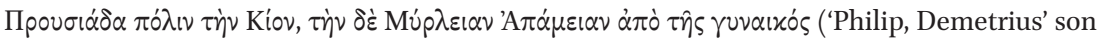
and Perseus' father, razed Cius and gave it to Prusias son of Zelas, who had helped him raze both Cius and the neighbouring city of Myrleia, which was also near Prusa: and he restored these cities from their ruins and gave Cius the further name Prusias after himself, and Myrleia the further name Apamea after his wife').

4 Memnon of Heracleia, $F G r H 434$ c. 27.

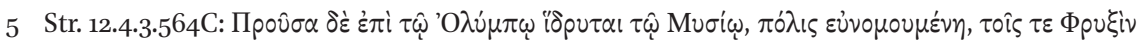

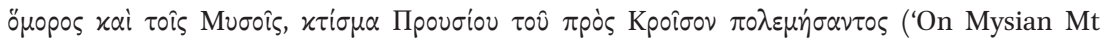
Olympus is built Prusa, a well-run city, adjacent to Phrygia and Mysia, the foundation of Prusias who fought against Croesus'); Plin. Nat. 5.148 credits Hannibal. 
the search for Greek pedigrees for their cities by the Bithynian kings, who were probably responsible for developing the Hylas festival involving oreibasia still celebrated in Strabo's time. ${ }^{6}$ The outcomes of this policy of hellenisation could be assessed by examining civic structures, ${ }^{7}$ relations between civic elites and monarchs, and festivals, though on all these our evidence is very patchy. In this paper I pick out one diagnostic phenomenon, the emergence of practitioners of high culture, as a palpable index of Hellenism, surveying the period from these cities' foundation to the middle of the third century AD: late in the third century Bithynia's intellectual landscape changed radically with the advance of Christianity and Diocletian's choice of Nicomedia for his capital.

\section{$2 \quad$ Practitioners of High Culture}

It is clear from my prosopography and table that whereas Myrleia and Chalcedon make some contribution before the third century BC, from no later than the second century вС Nicaea's cultural figures were more numerous and often more distinguished; only from late in the first century AD does Nicomedia begin to make a showing. There is a mere scattering of testimonies to high culture elsewhere. By contrast with Nicomedia and the other cities, the combination of a few literary sources, ${ }^{8}$ a catalogue of philosophers in the charred papyri of Herculaneum, and some notices in the late George of Cyprus, with the Suda entry on Nicaea, several inscriptions, and a remark in Athenaeus, allows us to assemble a substantial list of mathematicians,

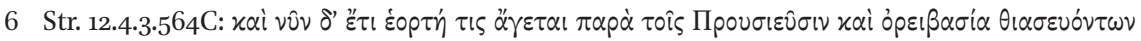

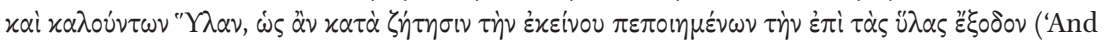
there is still a festival that the people of Prusias celebrate and roaming in the mountains by people who form cult-groups and call out "Hylas" just as was done by those who-during their search of Hylas- undertook the expedition into the forests'). The cult can be traced back to as early as the fifth century BC, cf. Sourvinou-Inwood 2005 .

7 For the magistracies and council in Greek cities of Bithynia after the Augustan modifications of the lex Pompeia see Ameling 1984; for their socio-political structures, Fernoux 2004.

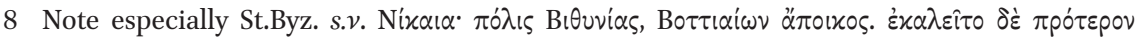

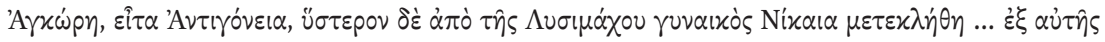

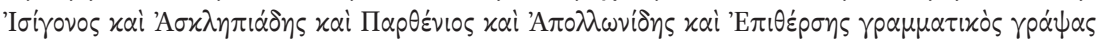

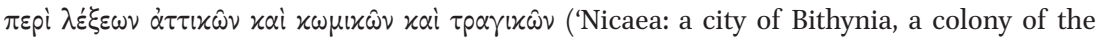
Bottiaeans. And it was previously called Ancore, then Antigoneia, and later its name was changed to Nicaea after the wife of Lysimachus ... from there came Isigonus and Asclepiades and Parthenius and Apollonides and Epitherses the grammaticus who wrote On Attic expressions in comedy and tragedy'). Some details may be drawn from Arr. Bithyni(a)ca, cf.

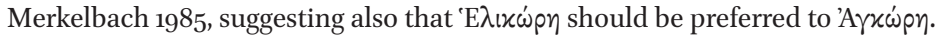


philosophers and literary figures from Nicaea, a list comprising some 30 individuals, among them no fewer than 9 philosophers.

Many of these 30 are hard, if not impossible, to date with any precision, so the attempt here made to chart Nicaea's cultural profile diachronically is necessarily extremely speculative (and for other Bithynian cities it would be impossible). But the astrologer Protagoras, for whom an epicedion was composed by Euphorion (b. 275 BC), can hardly have lived beyond the end of the third century $\mathrm{BC}$, and the astronomer Hipparchus is firmly located in the second half of the second century BC, even if more of his career was in Rhodes than Nicaea. This must also be the time of the Stoic Asclepiodotus, a pupil of Panaetius; of the Academic Bataces, a pupil of Carneades; and probably of the mathematician and astronomer Theodosius, with his sons a generation later. For the middle of the first century вс Parthenius' date and importance are certain. To its second half belongs the philosopher Apollos, with the epigrammatic poet Apollonides and the biologos Philistion certainly active under Augustus, as too, probably, the agricultural writer Diophanes. The Augustan period may also have seen a visit (admittedly to Nicomedia as well as to Nicaea) by the epigrammatist Diodorus of Sardis. From Tiberius' reign we know the grammaticus $^{9}$ and rhetor Epitherses Aemilianus, from a generation later his son Aemilianus-one of these also a poet of epigrams-, then at some date before the elder Pliny the grammaticus Isigonus, and before Plutarch the historian Menecrates.

There may be a thinning in the second century, as Nicomedia's importance grows. But the astrologer Antigonus belongs securely to Hadrian's reign, and from the century's end come the prominent figures of Cassius Dio and (it seems) Diogenes Laertius; perhaps also a mathematics teacher who died in Rome, Basileus. The pre-tetrarchic roll-call ends with a man who evokes the city's early giant, Hipparchus, a third-century commentator on Aratus called Sporus. From the third century вС to the third century AD, Nicaea enjoyed an apparently unbroken sequence of cultural activity despite occasional political turbulence.

I have recently sketched elsewhere at greater length the profiles of four of Nicaea's cultural eminences - the astronomer Hipparchus, the poet and prose mythographer Parthenius, the grammaticus and mythographer Asclepiades of Myrleia (originally from Nicaea), and the poet and scholar Apollonides. ${ }^{10}$ The prosopography of Nicaean cultural figures presented here merely registers

On grammatici see Bowie 2021 and the article on grammarians and emperors by C.P. Jones in this issue.

10 Bowie 2014; for Apollonides, Bowie 2012. 
these four, offering only cursory notices of them and of some other cities' figures (like Asclepiades and Dio from Prusa, or Arrian from Nicomedia) about whose careers much has been written.

On present evidence, other Bithynian cities had a much thinner cultural history. Only for Nicomedia are more than ten names listed, enough perhaps to explain why Athenaeus thought it both plausible and entertaining to include among his banqueters two fictional philosophers from Nicomedia, Democritus and Pontianus. ${ }^{11}$ Within the few figures attested for Prusa and Cius-Prusias ad mare doctors bulk large. But the great sophist Antonius Polemo visited Prusa to sample the eloquence of Dio, ${ }^{12}$ and an elegant epigram of unknown authorship praises Prusan springs on Mt Olympus with an enthusiasm that suggests its poet's visit. ${ }^{13}$ For Prusias ad Hypium, on the other hand, a philosopher Philippus mentioned by Plutarch and perhaps, before moving to Nicaea, the rhetor and grammaticus Epitherses, remain (despite several surviving inscriptions) our only evidence of homespun high culture. ${ }^{14}$ Moreover two cases of young men from Prusias who died studying elsewhere may suggest inadequate sophistic provision at home: certainly in the fourth century Himerius likewise left his native Prusias to study in Athens. ${ }^{15}$

One brief generalisation may be hazarded. Medicine and philosophy (in one case combined in the same individual, Menodotus of Nicomedia) are relatively well represented; scholars and grammatici (perhaps more engaged in teaching than scholarly activity) make a stronger showing than sophists. Poetry looks weakest: only of Parthenius do we have poems (and of these only

11 Ath. 1.1d. For Athenaeus' ludic presentation of philosophers see Bowie 2017.

12 Philostr. VS 1.25.539.

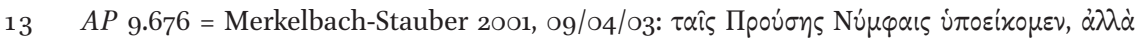

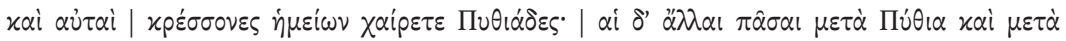

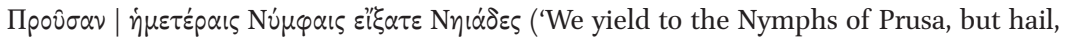
you Pythian Nymphs, who are also superior to us: but you other Naiads, after the Pythia and Prusa, should all yield to our Nymphs!').

14 The paideia praised in $I K 27$ no. 54 is not evidence that its bearer had been a professional

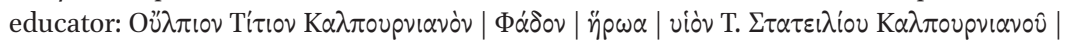

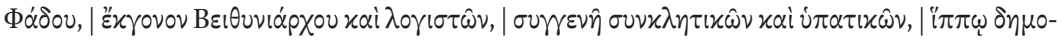

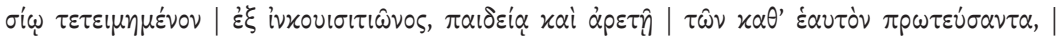

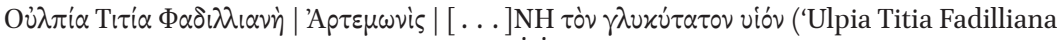
Artemonis [----] in honour of her sweetest son Ulpius Titius Calpurnianus Fadus, hero, son of Titus Statilius Calpurnianus Fadus, grandson of a Bithyniarch and of logistae, kinsman of senatorial and consular men, honoured by the equus publicus ex inquisitione, who achieved primacy in his generation in paideia and excellence').

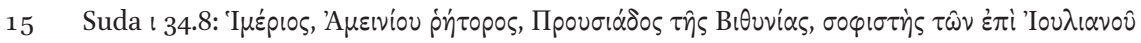
$\tau 0 \hat{v} \beta \alpha \sigma \lambda \lambda \varepsilon^{\prime} \omega \varsigma$... ('Himerius, son of the rhetor Ameinias, from Prusias in Bithynia, a sophist in the reign of Julian'). 
fragments) other than epigrams; and the 'literary' epigrams known to us are greatly outnumbered by the dedicatory and sepulchral poems of varying quality preserved on stone. Of 'literary' epigrams only several by Apollonides and a few by Aemilianus were taken into the Garland of Philip.

\title{
A Preliminary Prosopography of Practitioners of High Culture
}

\section{Apamea}

\author{
Philosophers ${ }^{16}$
}

o1. Lasthenes, represented in Philostratus' On Apollonius as having studied philosophy with Dio of Prusa, is almost certainly fictional. ${ }^{17}$

\section{Poets}

o2. Maximus, twice winner at Olympics (presumably local, not those at Pisa which had no musical agon), was commemorated by an honorific statue erected at Cyzicus in the second or third century AD: ${ }^{18}$

$$
\begin{aligned}
& \dot{\alpha} \gamma \alpha \theta \hat{\eta} \iota \tau \dot{x} \times \eta l^{\circ}
\end{aligned}
$$

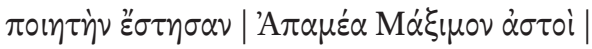

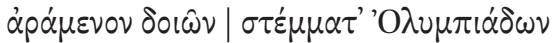

\section{With good fortune}

His fellow citizens set up a statue of the poet Maximus of Apamea who had won garlands in two Olympiads

\section{Rhetors}

o3. A Cleophanes or Cleochares figures in Strabo's short list of Bithynian intellectuals. ${ }^{19}$

16 Following the example of Geiger 2014, I leave blank numbers under each city in the expectation that more individuals will be identified; at the same time I begin each city's tally with 1,11 etc.

17 Philostr. VA 5·38.2.

18 IMT Kyz PropKueste no. 1869 (found near Edincik) = CIG 3672 = IGRom. iv $163=$ Stefanis 1988 , no. 1605 .

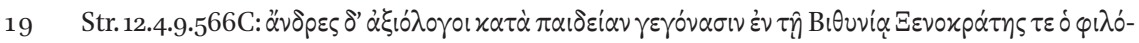

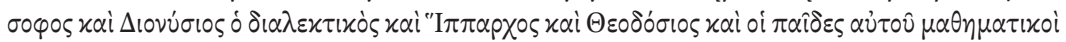

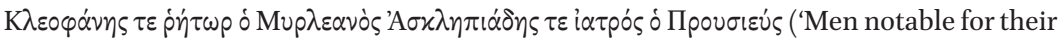
paideia from Bithynia have been the philosopher Xenocrates, the dialecticus Dionysius, the mathematicians Hipparchus and Theodosius and his sons, and the rhetor Cleophanes 


\section{Scholars}

04. Asclepiades, son of Diotimus, ultimately from Nicaea, according to the Suda, is regularly assigned to Myrleia. ${ }^{20}$ The Suda entry offers glimpses of his career: after some time when he was still young in Alexandria under a Ptolemy ${ }^{21}$ he taught in Rome in the time of Pompey. Strabo adds a career as a grammaticus in Turditania (Spain), of which he published a periegesis. ${ }^{22}$ His

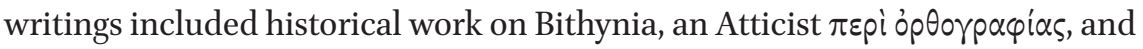
a mythological work used by Parthenius, also from Nicaea. ${ }^{23}$

\section{Students}

05. Nonius, who died at eighteen, was commemorated by his parents in a graveepigram followed by a prose text which Merkelbach and Stauber supplement to

from Myrleia and the doctor Asclepiades from Prusias'). I print the text of Radt 2002-2011,

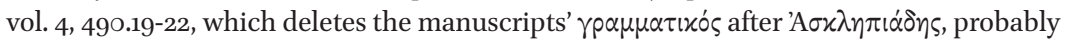

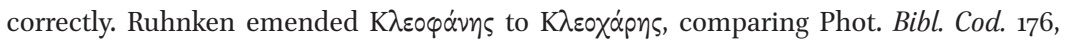
121b9-15, where Henri's 196o edition prints the manuscript reading $\Sigma \mu \nu \rho \lambda \varepsilon \alpha v o ́ \varsigma: ~ K \lambda \varepsilon o \chi \alpha ́ p \eta \varsigma$

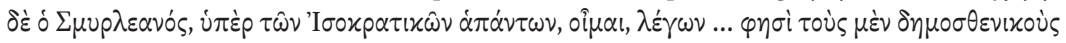

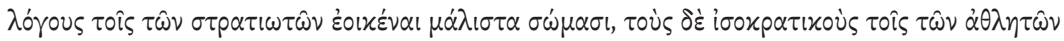
('Cleochares of Smyrleia, speaking, I think, on behalf of all Isocrateans ... says that the speeches of Demosthenes most resemble the bodies of soldiers, but those of Isocrates the bodies of athletes').

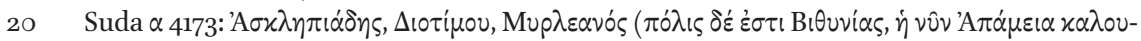

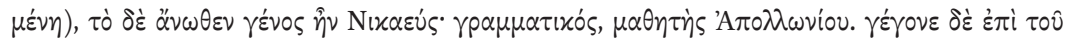

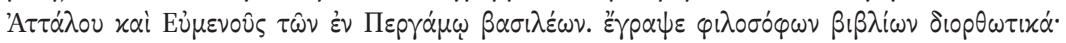

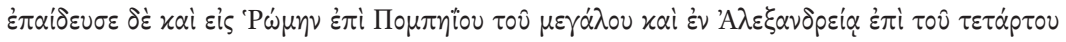

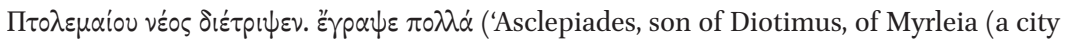
in Bithynia, now called Apameia) whose family originated in Nicaea: a grammaticus, pupil of Apollonius. He lived in the reigns of the Pergamene kings Attalus and Eumenes; he wrote works correcting the text of philosophical books. He also went to Rome to teach in the time of Pompey the Great and as a young man spent time in Alexandria in the reign of Ptolemy IV. He wrote many books'). For other testimonia, and fragments, see FGrH 697 . On his historiography, see Slater 1972.

21 Perhaps Ptolemy XII Auletes: the Suda text's specification of Ptolemy IV (see previous note) must be wrong, though apparently accepted by Corsten 1987, 11-12.

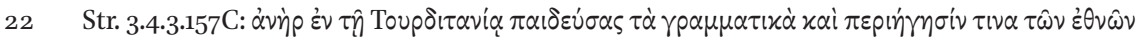
$\dot{\varepsilon} x \delta \varepsilon \delta \omega x \dot{\omega} \varsigma \tau \hat{\omega} \nu \tau \alpha \dot{v} \tau \eta$ ('a man who taught in Turditania and wrote a guide to the peoples of that area'), cf. 12.4.9.566C.

23 In Parth. Narr. 36, giving Asclepiades FGrH 697 F2 (the manchette assigning Narr. 35 to Asclepiades was seen by Sakolowski in his 1896 edition of Parthenius to belong to Narr. 36 , cf. Lightfoot 1999, 548). He was also used by Str. (see the preceding note); Ath. 2.5od-e (giving $\mathrm{FGrH} 697 \mathrm{~F} 4$, on the Bithynian bush-cherry); the scholia on A.R. (1.623-626a, giving FGrH 697 F5; 2.722, giving F6; 2.789-791a, giving FGrH 697 F3); the Vita Arati (giving F 11-13, where at p. 76.4 Maass the source of Fil is specified as $\dot{\varepsilon} \nu \tau \hat{\omega} \mid \alpha^{\prime} \pi \varepsilon p i \gamma p \alpha \mu \mu \alpha \tau i x \hat{\omega} \nu$, 'in book 11 of the work On matters grammatical'). See also Suda 0657 (Orpheus of Croton), $\pi 1888$ (Polemo of Ilium). 


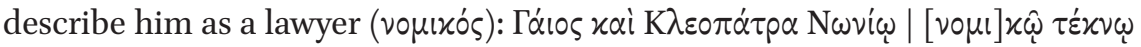
$i \delta i \omega \mu \nu \eta^{\prime} \mu \eta \varsigma \mid \chi \alpha \dot{p} \rho \nu$ ('Gaius and Cleopatra for their own son Nonius ... to commemorate him'). ${ }^{24}$ At eighteen, he could have progressed no further than study of law, and other supplements are possible (e.g. a second part of his name): this text does not establish the teaching or practice of law at Apamea.

\section{Bithynion-Claudiopolis}

\section{Doctors}

11 and 12. The professions of Acilius Theodorus and of his relative Theodorus who (with Acilius' son, also called Theodorus) built his tomb are identified in his epitaph, inscribed on a column. His relative's self-description as archiatros marks him as one of the city's official doctors who enjoyed immunity, as seen by Kaibel. That may also be indicated by Theodorus' own non-technical characterisation as 'foremost of doctors':

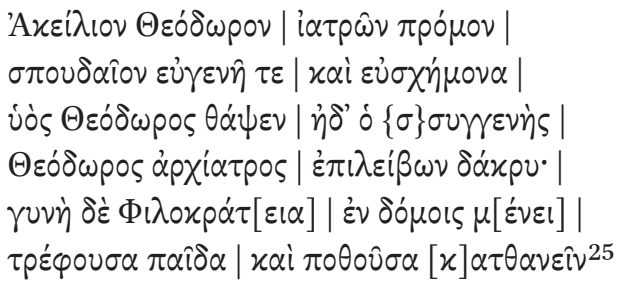

Acilius Theodorus, foremost of doctors, committed and noble and honourable was buried by his son Theodorus and his kinsman Theodorus, chief-doctor, who shed a tear over him: But his wife Philocrateia remains in their home bringing up their son and longing to die

13. An epitaph records a 'craftsman' Athenocles whose skills are almost certainly medical, indicated by the epithet $\eta \dot{\eta} \pi \iota^{\prime} \chi \varepsilon[1 p](\alpha)$ (line 3); a gap in the read-

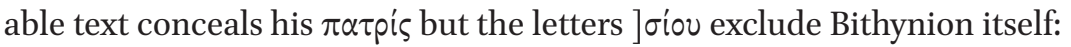

\footnotetext{
$24 I K 32$ no. $28=$ GVI 971 = Merkelbach-Stauber 2001, o9/o2/o1: the date is suggested to be first or second century AD by Peek, "unbestimmt" by Merkelbach-Stauber.

$25 I K{ }_{31}$ no. $72=$ IGRom. iii 77 = Epigr.Gr. $35^{2}=$ = GVI 686 = Merkelbach-Stauber 2001, o9/o9/o3, cf. Fernoux 2004, 491-492. For archiatroi see Nutton 1977, where the archiatros Theodorus is p. 223 no. 62 and is dated around AD 200 (but wrongly taken to be the deceased's son): Peek dated the inscription to the first or second century, Merkelbach-Stauber simply to the "Kaiserzeit".
} 


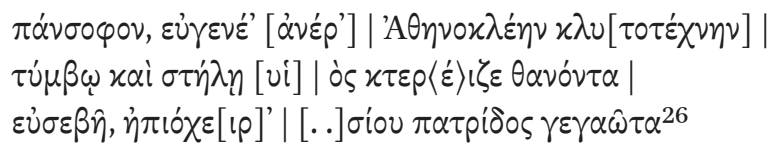

An all-skilful, noble [man], Athenocles, famed for his [craft] was given the burial honour on his death of a tomb and stele by his son: he was pious, and had a healing hand, and was born in the city of ...

\section{Philosophers}

14. The base for a possibly Hadrianic honorific statue describes Iulius Nicetes

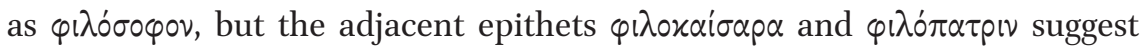
that mind-set, not profession, is being commended:

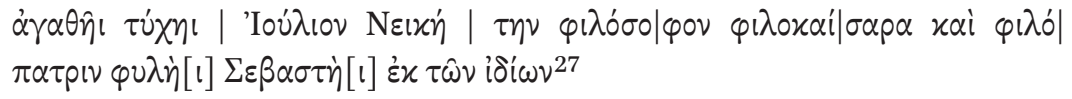

with good fortune Iulius Nicetes, wisdom-lover, Caesar-lover, and country-lover, (was honoured by) the tribe Sebaste using its own funds

\section{Rhetors}

15. The lexicographer Phrynichus may be from Bithynion. Summarising Phrynichus' Praeparatio Sophistica, Photius (Bibl. cod. 158) assigns him to the reigns of Marcus and Commodus and describes him as Arabian. ${ }^{28}$ The Suda, on the other hand, makes him Bithynian:

26 IK 31 no. 8 o cf. SEG 28.983, Şahin 1978, 52 no. 3, Merkelbach-Stauber 2001, og/og/o6 (date "unbestimmt").

$27 \quad I K 31$ no. 67.

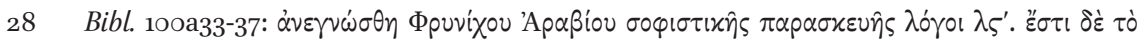

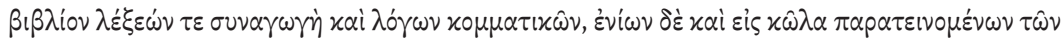

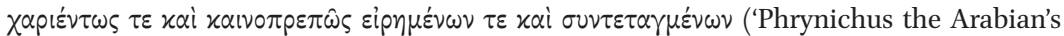
Preparation to be a sophist in 36 Books was read. The work is a collection of words and short phrases, some actually extending to sentences that have been expressed and

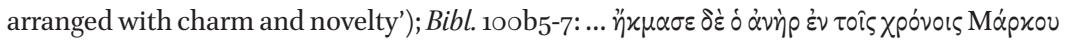

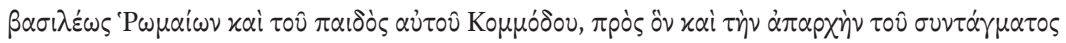

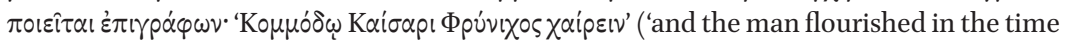
of the Roman emperor Marcus and his son Commodus, to whom in fact he dedicates the opening of the composition, with the preface "Phrynichus sends greetings to Commodus Caesar"). 


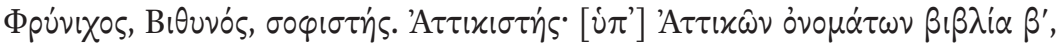

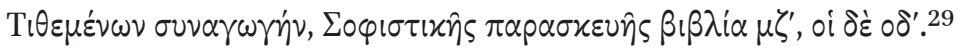

Phrynichus, of Bithynia, sophist, (called) the Atticist: 2 books of Attic words, a Collection of accepted usages, Preparation to be a sophist in 46 books (but some say 74 ).

If the Suda's Bı̈vvós is accepted, not Photius' 'Arabian', ${ }^{30}$ a refinement may be proposed. The Suda usually allocates individuals to cities, not to ethnic groups: might the Suda's text (or that of its source) originally have read

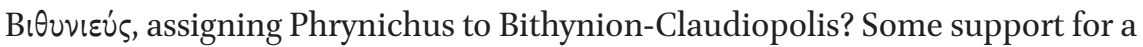

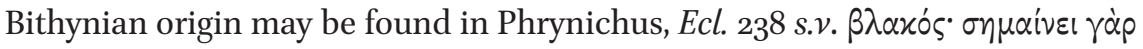

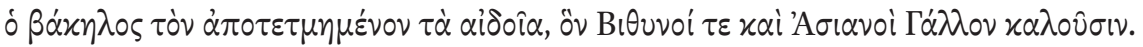

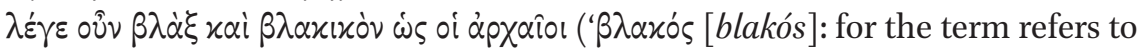
the man whose genitals have been cut off, whom Bithynians and Asians call a $\Gamma \alpha \dot{\lambda} \lambda$ os [Gallos]. So say $\beta \lambda \alpha \dot{\xi} \xi$ [bláx, 'fool'] and $\beta \lambda \alpha$ xixóv [blakikón, 'foolish'] like the ancients'). Many Greek writers might have enough knowledge of provincia Asia to point out the use of the $\Gamma^{\alpha} \alpha \lambda$ os there, but fewer had first-hand knowledge of Bithynia. ${ }^{31}$

16. Unknown: Two tablets, dated to the first century AD, preserve 40 and $3^{2}$ lines respectively of a long consolatory decree: the phraseology of the first (I 5 and 34-37) demonstrates that their subject, Theodorus, son of Attalus, from the community Pliny calls Agrippenses, ${ }^{32}$ came to Claudiopolis to study rhetoric with a teacher we cannot identify. ${ }^{33}$ Thus, despite the absence hitherto of

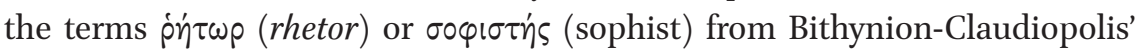

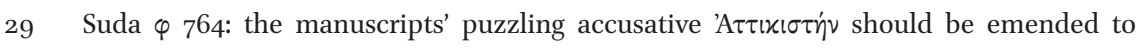

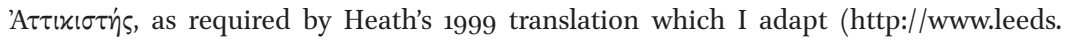
ac.uk/classics/heath/sudabits.html).

30 Schamp 1987, 210 (following $R E$ ) takes 'Apáßı⿻ to be a nickname; so too Janiszewski, Stebnicka and Szabat 2015, no. 846.

31 I am grateful to Dr Claudia Strobel for discussing this issue with me. For further discussion of Phrynichus see Strobel 2011.

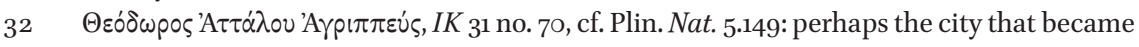
Crateia-Flaviopolis.

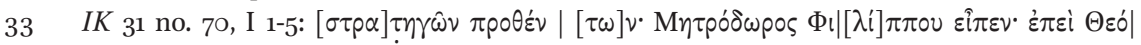

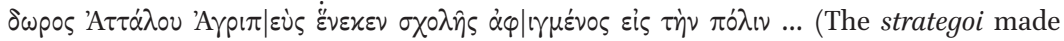
the proposal, Metrodorus, son of Philippus, spoke: 'Since Theodorus, son of Attalus, an

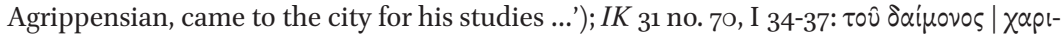

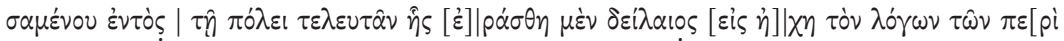

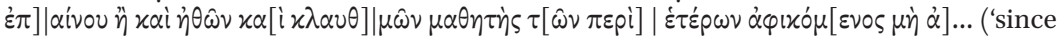
god has done him the favour of dying in the city with which he had fallen in love, poor youth, who came here to study as a pupil the ringing speeches addressing praise or 
scant epigraphy, some rhetorical education was apparently available. Little

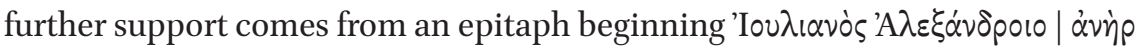

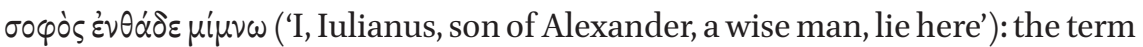
боৎós may simply claim enthusiasm for culture (a culture that did not extend to ensuring that his heirs inscribed verses that were properly metrical). ${ }^{34}$

\section{Students}

17. Theodorus son of Attalus went to Bithynion to study rhetoric, see above no. 16 .

\section{Caesarea Germanica}

Although we now know of one successful athlete from this small city which took its name from Germanicus, ${ }^{35}$ presumably during his eastern tour that began in $\mathrm{AD} 17$, and although, despite its size, Caesarea sent theoroi to Claros, ${ }^{36}$ nothing yet attests any intellectual activity there.

\section{Chalcedon}

\section{Doctors}

21. Herophilus, doctor and medical writer, ca. 330/320-26o/250 вс. Given a Hippocratic training by Praxagoras of Cos, he spent most of his career in Alexandria under Ptolemy I and II. Of eleven works attributed to him eight may be genuine. ${ }^{37}$

\section{Philosophers}

22. Dionysius, the dialecticus noted by Strabo, is the same as the Dionysius of Chalcedon assigned to the Megarian school by Diogenes Laertius, and perhaps the Dionysius criticised by Aristotle in the Topics: he flourished in the midfourth century вС..$^{38}$

character and lamentation that were about others....'), cf. Merkelbach 1984, 137-140, Puech 2002, no. 278 .

$34 I K 31$ no.77 = Merkelbach-Stauber 2001, o9/og/12 (who venture no date).

35 For the location of Caesarea Germanica, see Magie 1950, 497 with n. 18 (on p. 1357), superseded by Corsten 199o, publishing an inscription honouring its dolichos runner Tatianus son of Metrophanes; cf. Mitchell 1993, vol. 1, 212 with n. 84 .

36 See Ferrary 2005, $75^{8}$ (no earlier than AD 206/207); for the full Claros dossier see Ferrary 2014; for theoria Rutherford 2013.

37 See von Staden 1989 .

38 Str. 12.4.9.566C (printed above, n. 19), D.L. 2.106, Arist. Top. 148a26-31. 
23. Xenocrates son of Agathenor, the Academy's second head (339 to 312 BC) was from Chalcedon. ${ }^{39}$

24. The Stoic Apollonius, a teacher of Marcus Aurelius, assigned to Chalcedon by the Historia Augusta, ${ }^{40}$ is called 'Nicomedian' by Cassius Dio, himself from Nicaea. ${ }^{41}$ Perhaps Apollonius moved from Chalcedon to Nicomedia, as others apparently moved from smaller cities to Nicaea.

\section{Rhetors}

25. Thrasymachus, the fifth-century вс sophist who contributed significantly to the development of rhetorical theory, was from Chalcedon, though much of his activity seems to have been in Athens. ${ }^{42}$

\section{Students}

26. Themistocles, pupil of Apollonius (no. 24 above) ${ }^{43}$

\section{Cius-Prusias ad mare}

\section{Doctors}

31. The great Asclepiades is assigned to Prusias by Pseudo-Galen, Strabo and the elder Pliny. ${ }^{44}$ According to Pliny he became a doctor after failure as a rhetor. ${ }^{45}$ He practised in Rome with great success, perhaps after a period working in the Greek world, ${ }^{46}$ and was immensely influential on later medicine. He apparently died before the dramatic date of Cicero's De oratore, i.e. 91 BC. ${ }^{47}$ 32. A woman doctor Empeiria ('Experience') who died at 49, probably in the early empire, was buried by her husband C. Iulius Vettianus:

39 E.g. D.L. 3.46, 4.6.

40 SHA Vit. Marci 2.7 .

41 D.C. 71.35.1-2. He is the Apollonius magistro meo philosophiae of M. Aurelius' letter to Fronto 5.36 (= vol. 1, 234-237 Haines) (and presumably also of ad se ipsum 1.8 and 17): a son (also called Apollonius), in Rome when Marcus' letter was written (AD 153-154?), has commended to Marcus a pupil of his father called Themistocles. For Apollonius' role as tutor to Marcus cf. Luc. Demon. 31, SHA Vit. Pii 10.4, Vit. Marci 2.7, 3.1, PIR² A 929.

42 See Kennedy 1963, 68-80.

43 See Marcus' letter cited n. 41.

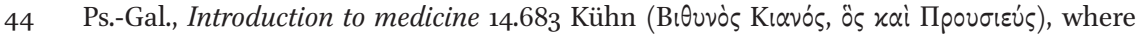
incorrectly Прovбías is printed (but see Rawson 1982, 359-36o); Str. 12.4.9.566C (printed above n. 19); Plin. Nat. 7.124.

45 Plin. Nat. 26.12-2O.

46 Two cases he treated in Parium are documented, Cael. Aurel. Acut. 2.129 and Oribas. CMG VI 2.1, 256 R, cf. Rawson 1982, 365 .

47 Cic. De orat. 1.62, cf. Rawson 1982, 36o-363. 


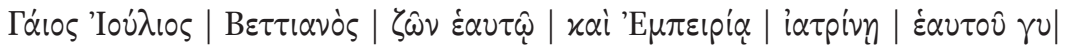

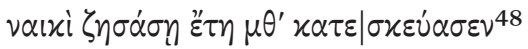

C. Iulius Vettianus built (this tomb) for himself during his lifetime and for the doctor Empeiria, his wife, who lived 49 years

\section{Crateia-Flaviopolis}

Philosophers (?)

41. A man whose name is lost is commended as a 'teacher of wisdom' ( $\sigma \circ \varphi$ ins $\delta เ \delta \dot{\alpha} \sigma x \alpha \lambda \varepsilon) \cdot{ }^{49}$

\section{Nicaea}

Astrologers/Astronomers/Mathematicians

51. Antigonus cast the horoscope of Hadrian and two other prominent contemporaries. ${ }^{50}$

52. Hipparchus' recorded observations range between 147 and 127 BC. Only his commentary on Aratus' Phaenomena survives, ${ }^{51}$ but imperial readers will have had access to much more, as is clear from Ptolemy's use of Hipparchus: in the reign of Alexander Severus Nicaean coins commemorate him, named and seated. His achievements in astronomy and mathematics would have been impossible without good knowledge of Babylonian work in these fields. ${ }^{52}$

53. Protagoras, often mentioned by Hephaestion of Thebes, who cites his Collections $(\Sigma v \nu \alpha \gamma \omega \gamma \alpha i)$, 53 is presumably Diogenes Laertius' astrologer $(\dot{\alpha} \sigma \tau p o-$ $\lambda$ ó$_{0}$ s) Protagoras, on whom Euphorion composed an epicedion: this dates him no later than Euphorion (born 275 BC). 54

54. Theodosius, whom the Suda calls a philosopher but credits with mathematical works, is secured for Bithynia by Strabo, whose listing of him next

$48 \quad I K 29$ no. $5^{2}=C I G 3736$.

49 Merkelbach-Stauber 2001, 09/10/04 (venturing no date).

$5^{\circ} \quad$ Heph.Astr. 2.18.21-66 (vol. 1, p. 157.28 ed. Pingree, Leipzig 1973); Cramer 1954, 165; Birley 1997,355 n. 26.

$5^{1} \quad$ For discussion and earlier literature see Lightfoot 2017. Bowie 2014, 36 wrongly describes Hipparchus' work on Aratus as a monograph, and erroneously (n. 3) attributes to the reign of Pius the Nicaean coins that represent Hipparchus.

52 Cf. Toomer and Jones 2012; for a fuller discussion of Hipparchus' achievements, Neugebauer 1975, 274-278; for the coins, RPC VI, nos 3194, 3244 5898, 5899.

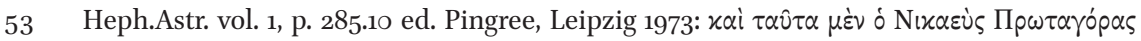
('and that is what is said by the Nicaean Protagoras'), cf. ibid. p. 323.6: $\varepsilon$ ¿ $\tau \hat{\omega} v \Sigma v v \alpha \gamma \omega \gamma \hat{\omega} v \tau 0 \hat{v}$

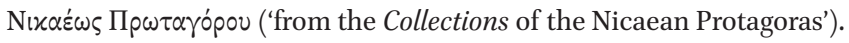

D.L. 9.56 . 
to Hipparchus may indicate Nicaean origin. ${ }^{55} \mathrm{He}$ is probably the Theodosius named by Vitruvius as the inventor of a universal sundial. ${ }^{56}$ Of his writings

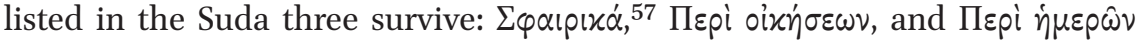

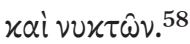

\section{Doctors}

55. Antigonus. ${ }^{59}$

56. Hedys is commemorated in a verse epitaph, probably of the second or third century $\mathrm{AD}$, as having travelled as far as the ocean, visiting Europe, Africa and Asia:

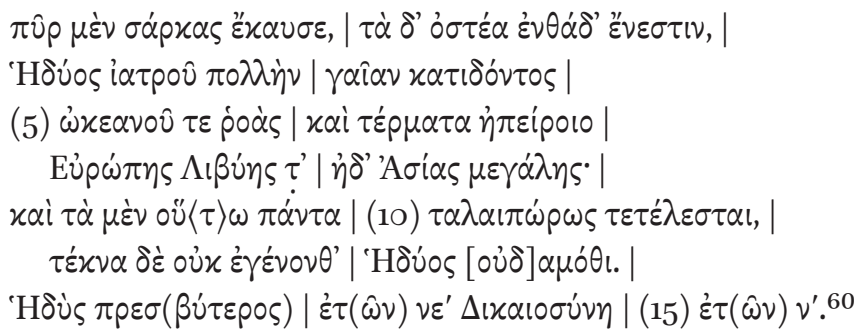

Fire burned his flesh, but here lie the bones of the doctor Hedys, who beheld many a land and the streams of the Ocean and the limits of the continent

of Europe, and of Africa, and of mighty Asia: and all these things were thus achieved with toil, but children of Hedys are to be found nowhere. Hedys the elder, 45 years; Dicaeosyne, 40 years.

55 Suda $\theta$ 142: $\Theta \varepsilon 0 \delta$ ó

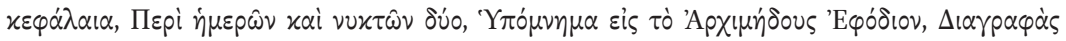

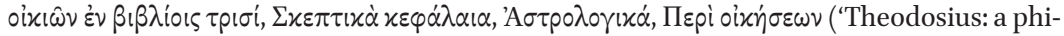
losopher. He wrote Spherics in 3 books, a commentary on the Summaries of Theudas, On Days and Nights, 2 books, a commentary on the Method of Archimedes, Specifications of Houses in 3 books, Research summaries, Astrologics, On Habitations'); cf. Str. 12.4.9.566C, cited above, n. 19 .

56 Vitr. 9.8.1.

57 Ed. J.L. Heiberg, Abhandlungen der Gesellschaft der Wissenschaften zu Göttingen, Philol.-hist. Kl. N.F. 19.3. Berlin: Weidmann, 1927, pp. 1-164.

$5^{8}$ Ed. R. Fecht, Abhandlungen der Gesellschaft der Wissenschaften zu Göttingen, Philol.-hist. Kl. N.F. 19.4. Berlin: Weidmann, 1927, pp. 1-154.

59 Cod. Vatican. 299, cf. Rohde 1873.

6o $I K 9$ no. $175=$ GVI 1749 = Merkelbach-Stauber 20o1, o9/05/12, taking $\pi \rho \varepsilon \sigma(\beta u ́ \tau \varepsilon \rho \circ \varsigma)$ in line 14 to indicate Hedys was a Jewish or Christian presbyter: but it may simply distinguish him from a younger family member, e.g. a homonymous cousin. 


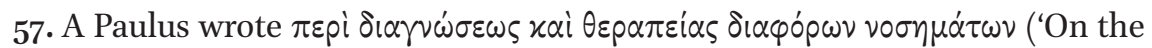
diagnosis and treatment of various diseases' ${ }^{6}{ }^{61}$

58 and 59. Pisistratus, son of Pisistratus, grandson of Biteuas, and Apollodotus, son of Peisistratus, are commemorated in a family tomb:

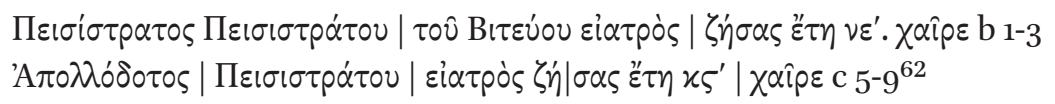

Pisistratus, son of Pisistratus, son of Biteuas, a doctor, who lived 45 years. Farewell.

Apollodotus, son of Peisistratus, a doctor, who lived 27 years. Farewell.

6o. A doctor whose name is not given was buried, aged 61, at Pythion in Perrhaebia:

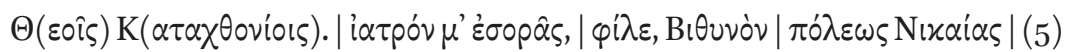

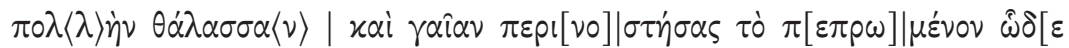

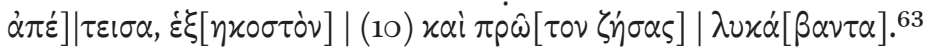

To the gods beneath the earth. You see me, friend, a Bithynian doctor from the city of Nicaea, who travelled around much land and sea and paid his fated due here, having lived his sixty-first year.

\section{Historians}

61. L. Cassius Dio (Cocceianus?), born c. AD 164 and of Nicaean origin, was praetor in AD 194 under Pertinax and cos. suff., probably c. AD 204, under Septimius Severus; ${ }^{64}$ in AD 214/215 he wintered with Caracalla in Nicomedia. ${ }^{65}$ Macrinus appointed him curator of Pergamum and Smyrna in AD 217/218. At the start of Severus Alexander's reign he was proconsul of Africa, then governed Dalmatia and Upper Pannonia. ${ }^{66} \mathrm{He}$ was consul ordinarius (with Severus Alexander as his colleague) in AD 229, then returned to Bithynia. ${ }^{67}$ For his 8o-book history of Rome he spent ten years collecting materials down to the

\footnotetext{
61 Diller, RE XVIII col. 2397, no. 25 .

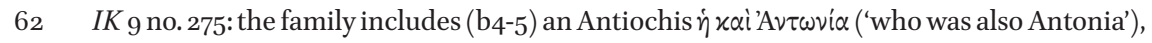
which shows the date to be late republican or imperial.

$63 I G$ ix 2.1276 ('undated'): for the site see Lucas 1992, 93-137.

64 D.C. $75 \cdot 15 \cdot 3$, 73.12.2, 76.16.4, cf. 6o.2.3. On Dio Millar 1964 remains important: see also Manuwald 1979; Fechner 1986; Gowing 1992; Madsen 2019.

65 D.C. $77 \cdot 12.2-3,18.4,78.8 .4-5$.

66 D.C. $49 \cdot 36.4,80.1 .2-3$.

$67 \quad$ D.C. $80.4 \cdot 2-80 \cdot 5 \cdot 3$.
} 
year 211 and twelve more writing up. ${ }^{68}$ His other works included a Life of his fellow Bithynian Arrian.

62. A Menecrates wrote (earlier than Plutarch) a history of Nicaea: it mentioned Antiope, Theseus, and his foundation of Pythopolis on the southern shore of Lake Nicaea. ${ }^{69}$ Its mention of Heracleia was also known to Tzetzes. ${ }^{70}$ 63. Philippus, termed ourpa of oracles, claims Epitherses as his fellow-citizen. ${ }^{71} \mathrm{He}$ should thus be from Nicaea if, as seems likely, that was Epitherses' origin (see below nos. 75 and 83) and should probably be distinguished from the Philippus presented as a Stoic from Prusias in Quaestiones convivales (below no. 131).

\section{Mime Writers and Performers}

64. The biologos Philistion, active under Augustus ${ }^{72}$ and called ridiculus ('jocular') by Martial, ${ }^{73}$ is termed Nicaean by an epigram in the Anthology of unknown authorship, quoted also by the Suda, which initially allocates him to Prusa or (following Philo) to Sardis. ${ }^{74}$ He may have started life in Prusa and moved to Nicaea, as apparently did Parthenius from Myrleia.

\section{Philosophers}

65. Apollos is described by George of Cyprus as a Stoic, and a pupil of Apollonius who succeeded Dardanus, putting him later than the mid-first century вс. ${ }^{75}$

$68 \quad$ D.C. $72.23,74 \cdot 3$.

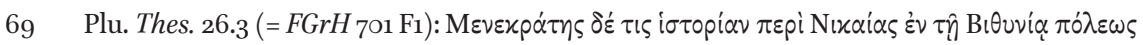
$\varepsilon x \delta \varepsilon \delta \omega x \omega$ ऽ ('A certain Menecrates who published a history of Nicaea the city in Bithynia').

70 On Lycophron 663 (= Menecrates $\mathrm{FGrH}_{701 \mathrm{~F} 2}$ ).

71 Plu. De def. orac. $17=$ Mor. 419 b; $15=$ Mor. 418 a for his being a historian.

72 Jerome, based on Eusebius, puts him in the second year of the 196th Olympiad, i.e. AD 5 .

73 Mart. 2.41.15. That he invented the mime (Cassiod. Var. 4.51) probably confuses him with Philemon.

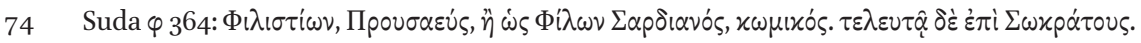

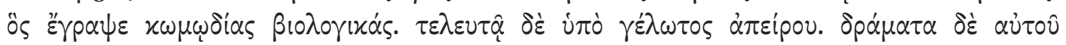

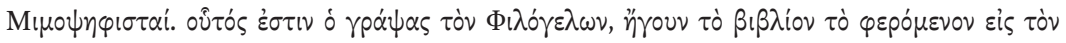

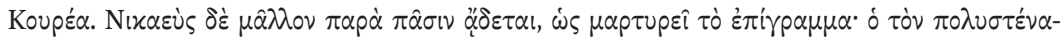

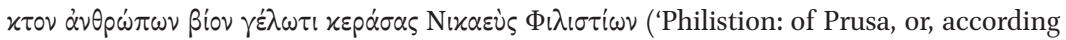
to Philo of Sardis, a comedian. He died at the time of Socrates. He wrote comedies drawn from life. He died of laughter that would not stop. His plays included Mime-voters. This is the man who wrote the Philogelos, i.e. the book presented to Coureus. But he is famed by everybody as rather from Nicaea, as the epigram testifies: "Philistion of Nicaea, who blended the miserable life of mankind with laughter"'); the epigram is also $A P$ 7.155.

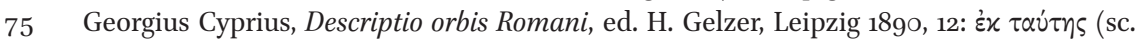

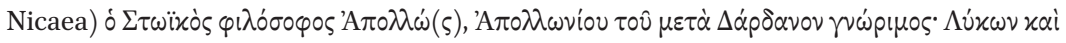

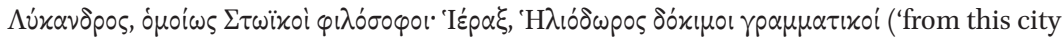
came the Stoic philosopher Apollos, a pupil of the Apollonius who succeeded Dardanus; 
66. Asclepiodotus, son of Asclepiodotus and pupil of Panaetius, is known from the Index Stoicorum Herculanensis. ${ }^{76} \mathrm{He}$ may be different from the Asclepiodotus who was a pupil of Posidonius (auditor Posidonii) and is also taken to be the writer of the $\tau \varepsilon \chi \nu \dot{\eta} \tau \alpha \varkappa \tau i x \dot{~(' M a n u a l ~ o n ~ t a c t i c s ') . ~}{ }^{77}$

67. M. Atinianus $\varphi 1 \lambda$ ó $\sigma 0 \varphi \varsigma$ ('philosopher') is epigraphically attested. ${ }^{78}$

68. Bataces is registered as a pupil of Carneades (and so should be active in the mid or later second century вС) in the Index Academicorum Herculanensis. ${ }^{79}$

69 and 70 . Lycander and Lycon are Stoic philosophers known from the Index Stoicorum Herculanensis and George of Cyprus. ${ }^{80}$

71. Mentor is registered as a pupil of Carneades in the Index Herculanensis. ${ }^{81}$

72. A Nicias is cited by Athenaeus for his claim that Alexamenus wrote dialogues before Plato. ${ }^{82}$

73. Sedatus Theophilus, praetorius, fellow incubant with Aristides at the Pergamene Asclepieion in the $140 \mathrm{Os},{ }^{83}$ was suggested by Fernoux 2004 to have been a philosopher, but this is not implied by Aristides' text.

\section{Poets}

74. Parthenius, born in Myrleia, is more often associated with the city of Nicaea, to which he moved, presumably before being captured and taken to Rome in

Lycon and Lycander, likewise Stoic philosophers; Hierax and Heliodorus, famous gram-

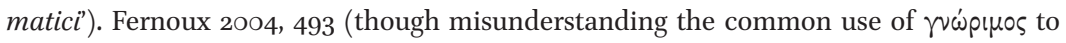
mean 'pupil') suggests, following Merkelbach 1985, 1-3, that the detail derived from Arr. Bithyni (a)ca.

76 Index Stoicorum Herculanensis, ed. Traversa, Genoa 1952, col. 53 p. 73.3, cf. DPhA A 455, IK 10.3 p. 83 .

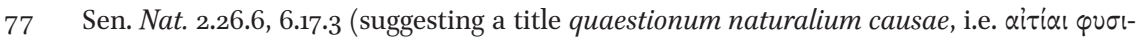
x $\alpha^{\prime}$, 'Physical causes'); he is also cited ibid. at 2.30.1, 5.15.1, 6.22.1-2.

$78 \quad$ IK 10.3 p. 10o, cf. Bull. 1958, no. 84.

79 Index Academicorum Herculanensis, ed. S. Mekler, Berlin 1902, 85, 105.

8o Index Stoicorum Herculanensis, ed. Traversa, Genoa 1952, cols. 75 (p. 95) and 76 (p. 97), cf. IK 10.3 p. 100.

81 Index Academicorum Herculanensis, ed. S. Mekler, Berlin 1902, 86. For the relevant passage of George of Cyprus see above n. 75 .

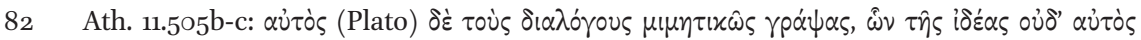

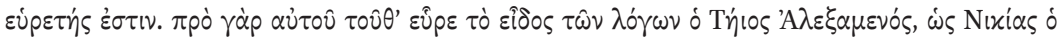

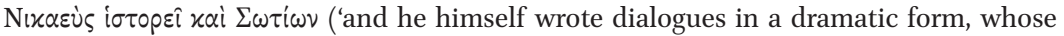
genre he did not in fact invent himself. For before him this form of prose writing was invented by Alexamenus of Teos, as is recounted by Nicias of Nicaea and by Sotion'). Cf. $I K$ 10.3 p. 86, suggesting Nicias' date might be Neronian.

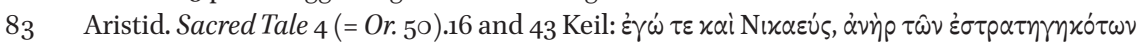

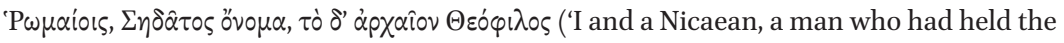
Roman praetorship, called Sedatus, but previously Theophilus'), cf. Sacred Tale 2 (= Or. 48).48 Keil. 
the third Mithridatic war. ${ }^{84}$ Macrobius says he was Vergil's teacher in Naples, ${ }^{85}$ his poetry was liked and imitated by the emperor Tiberius, ${ }^{86}$ and he figures along with Callimachus in an epigram by the early second-century scoptic poet active in Smyrna, Pollianus. ${ }^{87}$

\section{Rhetors}

75. Aemilianus, son of the Nicaean Epitherses of Plutarch's On the decline of oracles (below no. 84) is said by the character Philippus to have been a rhetor heard by some of those present; the dialogue may be set in AD 83/84. ${ }^{88}$ That he was the rhetor Aemilianus mentioned by the elder Seneca was convincingly questioned by Bowersock, proposing that Plutarch's 'old man Aemilianus'

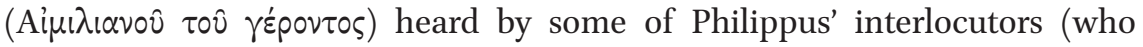
corroborate his anecdote about a voice proclaiming (Pan is dead') is in fact Aemilianus' father, whose name will have been Epitherses Aemilianus. ${ }^{89}$ 76. A rhetor Arche[polis] or Arche[moros] was buried at Thessalonice:

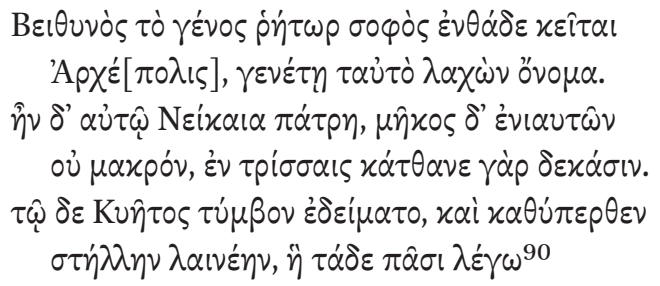

84 Suda $\pi$ 664. Full discussion in Lightfoot 1999.

85 Macr. Sat. 5.17.18.

86 Suet. Tib. 70: fecit et Graeca poemata imitatus Euphorionem et Rhianum et Parthenium, quibus poetis admodum delectatus scripta omnium et imagines publicis bibliothecis inter ueteres et praecipuos auctores dedicauit; et ob hoc plerique eruditorum certatim ad eum multa de his ediderunt ('He also composed poems in the manner of Euphorion, Rhianus and Parthenius, poets whom he very much liked: he had the writings and busts of all of them set out in public libraries among the old, canonical writers; and for this reason several of the scholarly community competed with each other in publishing many works about these poets for him').

$87 \quad A P$ 11.13o. On Pollianus see Nisbet 2003, 182-194.

88 Plu. De def. orac. $17=$ Mor. 419 b, and for the date $1=$ Mor. 41oa; cf. Janiszewski, Stebnicka and Szabat 2015, no. 27.

89 Sen. Con. 10.5.25. Bowersock 1965a, 268-269, rejecting the tentative identification of PIR A318: corroboration by interlocutors, Plu. De def. orac. $17=$ Mor. $419 \mathrm{e}$.

9o $\quad$ IG $\times 2.512=$ GVI 717, probably second century AD, cf. Puech 2002, no. 34, noting that Arche[polis] or Arche[moros] are possible. Janiszewski, Stebnicka and Szabat 2015, no. 139, following Peek, favour Arche[polis]. 
Bithynian by birth, a wise rhetor lies here, Arche[polis?], who got the same name as his father.

Nicaea was his home country, and the length of his years was not long, for he died in three decades.

For him Quietus built a tomb, and above it a stone stele, me, who tell everybody these things

77 (?) and 78 (?). Rhetorical activity may be behind the commendations of P. Catillius Macer, 'outstanding in character and paideia', made citizen and bouleutes at Delphi in AD 129, ${ }^{91}$ and (C. Cassius?) Sacerdos, praised in one of

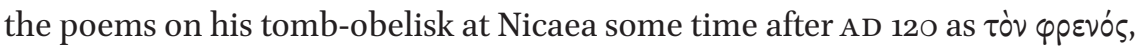

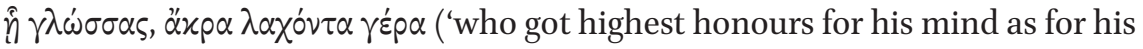
tongue'). ${ }^{92}$ But in each case general cultural eminence may be meant.

79. A man named Euandros is attested as a $\dot{p} \dot{\eta}[\tau \omega \rho$ ?] in a verse inscription from Nicaea accompanying a dedication to Zeus. ${ }^{93}$

Scholars, grammatikoi, philologoi

8o. Agathocles, described as $\varphi 1 \lambda \hat{\lambda}^{\lambda}$ oros, died at Smyrna at twenty, at this age more probably a student than a teacher of logoi:

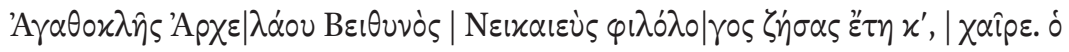
$\tau 0 \hat{\tau} \tau \alpha \alpha\left|\tau \alpha \lambda \dot{\sigma} \sigma \alpha \varsigma \delta \omega^{\prime} \sigma \varepsilon l\right| \tau \hat{\eta} \pi \dot{\lambda} \lambda \varepsilon l$ 米 $\varphi^{\prime 94}$

Agathocles, son of Archelaus, a Bithynian from Nicaea, lover of logoi, who lived 20 years. Farewell. Anyone who destroys this will pay the city 500 drachmas

81. That the poet Apollonides whose epigrams were included in his Garland by Philip of Thessalonice around AD 6o is identical with the scholar who dedicated a commentary on Timon of Phlius' Silloi to the emperor Tiberius is

\footnotetext{
91 Delph. 3(2), $102=$ Syll. $^{3} 836$, cf. Bowie 2014, 43-44.

92 AP 15.5.6. On these 5 poems and Chrestus' identity see Merkelbach 1987; MerkelbachStauber 2001; Bowie 2014, 40-43; Janiszewski, Stebnicka and Szabat 2015, no. 917. Another Nicaean Cassius, P. Cassius Epigenes, honoured a priest at the Pergamene Asclepieion late in the 2nd or early in the 3 rd c., Inscr.Perg. iii 47.

93 IK 10 no. 1136 = Merkelbach-Stauber 2001, o9/o5/o2 (offering no date): Janiszewski, Stebnicka and Szabat 2015, no. 326.

94 IGRom. iv $1446=I K 23$ no. 439 (undated).
} 
probable, albeit unprovable. ${ }^{95}$ It is uncertain where he was chiefly active-the dedication to Tiberius might suggest Rome, or Rhodes, but requires neither. Many of Philip's poets have north Aegean links, and Apollonides may simply have stayed in Nicaea. ${ }^{96}$

82. Diogenes Laertius was probably Nicaean. In mentioning Apollonides (see

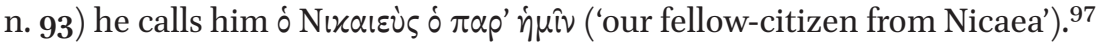

83. A Diophanes from Nicaea is among 'foreign sources' (externi auctores) cited by Pliny in his first book as a source for Book 10 of Natural History (on birds). This may be the Diophanes who wrote a six-book epitome of Cassius Dionysius of Utica's Greek abridgement of Mago's agricultural work, addressed to king Deiotarus of Galatia (who died in $40 \mathrm{BC}$ ), which was in turn further abridged by Asinius Pollio of Tralles around AD 100; but Pliny lists them separately, as if they were different. ${ }^{98}$

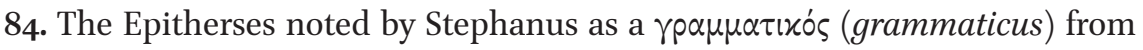

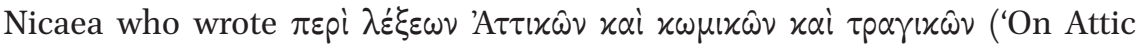
expressions in comedy and tragedy'), ${ }^{99}$ and who is cited by Erotianus, ${ }^{100}$ is probably the Epitherses mentioned as his countryman and teacher of

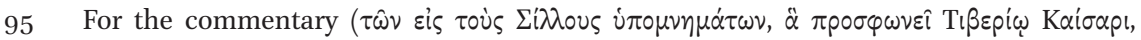
'the Commentaries on the Silloi which he dedicates to Tiberius Caesar') see D.L. 9.1og. In favour of identifying the two see Gow-Page 1968, vol. 2, 147-148; Bowie 2012, 229-230. On Apollonides see further Bowie 2012, 239, and 2014, 37. Later, under the Severi, conceivably from the same family, note T. Aur. Calpurnianus Apollonides, whose procuratorial followed a military career, IK 29 no. $58, I L S$ 885o, Madsen 2009, 74 with n. 98.

97 D.L. 9.109, cf. Mejer 1978.

98 Plin. Nat. 1.36: Diophane Nicaeense ... Dionysio qui Magonem transtulit. Diophane qui ex

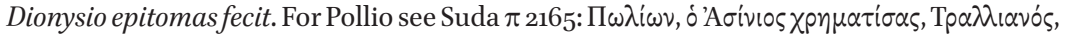

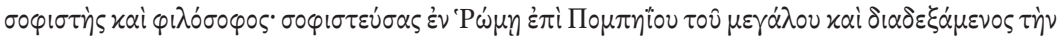

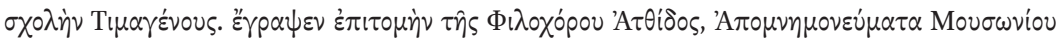

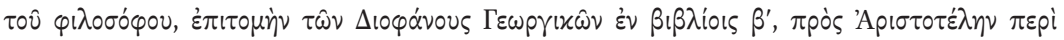

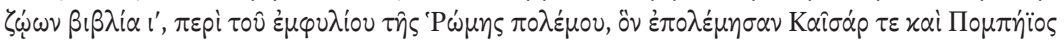
('Pollio, who had the name Asinius; of Tralles, a sophist and philosopher. He practised as a sophist in Rome in the time of Pompey the Great, and succeeded Timagenes as the head of his school. He wrote an epitome of Philochorus' Atthis, Memoirs of the philosopher Musonius, an epitome of Diophanes' Georgics in 2 books, Against Aristotle "On Animals" (10 books), On the Roman civil war fought between Caesar and Pompey'). The entry confuses the late republican and Augustan C. Asinius Pollio (to whom belong the Pompeian date and the work on the civil war) and the later sophist and philosopher whose work on Musonius should post-date his death (late 1st c. AD but before 10o/101); cf. Schmid-Stählin ${ }^{6}$ vii.2.1 (1920) 291, Jacoby on FGrH 193.

99 St.Byz. s.v. Níxal $\alpha$. Cf. the Epitherses from Nicaea $I K$ no. 101, but also two, father and son, from Prusa, $I K 39$ no. $115=$ SEG 49.1796.

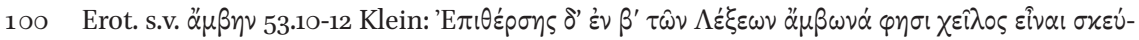
ous ('Epitherses says in Book 2 of Expressions that the ambon is the lip of a vessel'). 


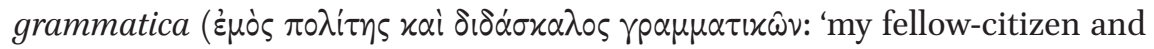
a teacher of things grammatical') by the character Philippus in Plutarch's dialogue On the decline of oracles in an anecdote anchoring Epitherses in Tiberius' reign, ${ }^{101}$ and the Aemilianus known as a rhetor to the the elder Seneca. ${ }^{102}$ His name will have been Epitherses Aemilianus; ${ }^{103}$ his son mentioned by Plutarch, the rhetor Aemilianus, is registered above no. 75. Either father or son might be the Aemilianus of Nicaea to whom the Palatine Anthology credits AP 9.218= Gow-Page 1968, Aemilianus i, an 8-line epigram spoken by a ship whose passengers have drowned in a storm, and presumably the Aemilianus there credited with $A P 7.623$ and 9.756 (= Gow-Page 1968, Aemilianus ii and iii), the latter a poem on Praxiteles' marble Sileni, a sculpture once owned by Asinius Pollio and to be seen in Rome. ${ }^{104}$ If the Philippus of Plutarch's On the decline of ora-

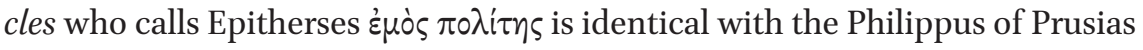
in his Sympotic questions $(Q C$ 7.7.1 $=$ Mor. $710 \mathrm{Ob})$ it is possible that Epitherses' origin was Prusias, but that he moved to the intellectually more stimulating Nicaea (as did Parthenius from Myrleia, see above no. 74). But see above on no. 63 .

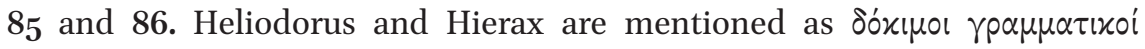
('famous grammatici') by George of Cyprus (above n. 75).

87. The Isigonus picked out by Stephanus of Byzantium s.v. Níxal $\alpha$ (above n. 8) is the Nicaean Isigonus referred to three times by Pliny:105 he wrote $\pi \varepsilon p i \dot{\alpha} \pi \dot{i}-$ $\sigma \tau \omega \nu$ ('On incredible things') and $\pi \varepsilon p i$ ' I $\tau \alpha \lambda \iota \kappa \omega \nu \nu \varepsilon \varepsilon \omega \nu$ ('On Italian gods').

88. Sporus, who edited and commented on Aratus in the third century AD, wrote a miscellanistic work entitled $x$ ¡ pi $\alpha$ ('Honeycombs'). ${ }^{106}$ In choosing to comment on Aratus he was following the famous Hellenistic Nicaean astronomer Hipparchus (above no. $\mathbf{5}^{2}$ ), who wrote a commentary on the Phaenomena.

\section{Teachers}

89. Basileus, a teacher of mathematics, died in Rome in the late second or early third century AD:

\footnotetext{
101 Plu. De def. orac. $17=$ Mor. 419 b.

102 Sen. Con. 10.5.25.

103 As argued by Bowersock 1965a.

104 See Bowie 2012, 224.

105 Plin. Nat. 7.12, 16, 27.

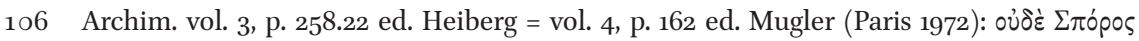

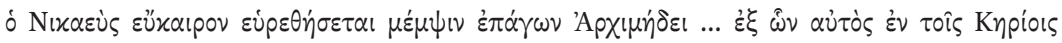

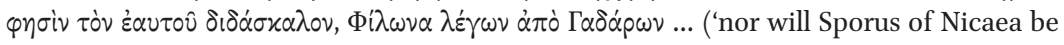
found to be levelling timely criticism against Archimedes.... on the basis of which in The Honeycombs he says that his own teacher, meaning Philo of Gadara, ...'), cf. also p. 76.1. For Philo of Gadara see Geiger 2014, 32.
} 


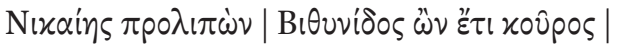

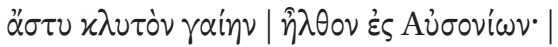

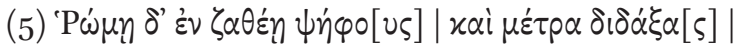

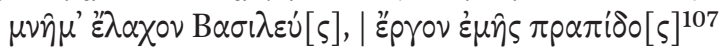

When I was still a youth I left Bithynian Nicaea's renowned city, and came to the land of the Ausonians:

in holy Rome I taught arithmetic and geometry and I, Basileus, got this memorial, the work of my mind

\section{Visitors}

9o. An elegant sepulchral epigram for inscription upon an imposing tomb was composed for the Nicaean Achaeus, son of Diomedes, by a Diodorusprobably the younger Diodorus of Sardis, poet and historian, and a friend of Strabo. ${ }^{108}$ This does not prove a visit by Diodorus to Nicaea, but his eastern Aegean links render it not improbable.

\section{Nicomedia}

\section{Astrologers/Astronomers/Mathematicians}

101. Ti. Claudius Oclatius Dionysius (perhaps first century AD) is represented on his tombstone in the posture of an intellectual, seated, with a book-roll on a table between him and his wife, and identified as an astrologer (mathematicus):

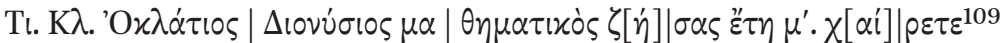

Tiberius Claudius Oclatius Dionysius, astrologer, who lived 40 years. Farewell

\section{Doctors}

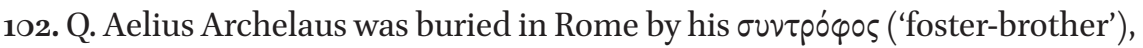
Q. Aelius Tertianus, having died after much travel to attend his patients. ${ }^{110}$ His usual dating to the second century $\mathrm{AD}$ on the basis of his nomen might

\footnotetext{
$107 \quad I G U R$ iii $1176=I G$ xiv $1500=G V I 1042$.

108 AP 7.701 = GVI 664 = Gow-Page 1968, Diodorus $\mathrm{x}=$ Merkelbach-Stauber 2001, o9/o5/o9; Str. 13.4.9, 627-628C. For the problem of dividing poems between him and his father Diodorus Zonas see Gow-Page 1968, vol. 2, 263-264, and for brief discussion of his poetry Bowie 2012, 235, 247. For another imposing tomb whose inscriptions reached the Anthology see above no. 78 Sacerdos.

109 TAM iv 200, cf. Fernoux 2004, 493.

$110 I G$ xiv $2019=I G U R 299$.
} 
be wrong. The praenomen Quintus points rather to the family of the consul of 11 BC, Q. Aelius Tubero, whose father was the patron of Dionysius of Halicarnassus, a family with which Strabo, too, may have had links; but the lettering strongly favours, though does not prove, the later date. ${ }^{111}$ 103. Flavius Atticus is known from his tombstone:

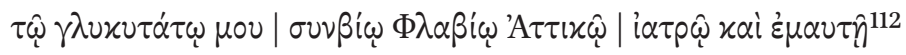

For my sweetest husband Flavius Atticus, a doctor, and for myself

104. Menodotus is known from Diogenes Laertius as a medical doctor and an empiricist philosopher, a pupil of Antiochus from Laodicea ad Lycum, and teacher of Sextus Empiricus' teacher, Herodotus of Tarsus. ${ }^{113}$ This sequence sets him near the mid second century AD.

\section{Philosophers}

105. L. Flavius Arrianus, known to contemporaries as a philosopher as well as historian, ${ }^{114}$ attended the lectures of the Stoic Epictetus at Nicopolis, probably c. AD 108, later (perhaps c. 120) writing them up in what became a classic Stoic text 'Lectures of Epictetus'.115 His senatorial career perhaps included participation in Trajan's Parthian campaign (one subject of his seventeen-book Parthica) and the proconsulate of Baetica; certainly a suffect consulate (c. AD 129) and 6 years governing the military province of Cappadocia (AD 131-137). Like his

111 D.H. Th. 1 and 55; for Strabo's possible links with the Aelii see Bowersock 1965b, 128-131. I am very grateful to Michael Crawford for giving me his expert opinion on the letter forms (visible in the drawing in Ferrua 1966, 29 fig. 4b).

112 Şahin (1973-1974) no. 13.3-5, TAM iv 220.3-5, Bull. 1974, no. 573.

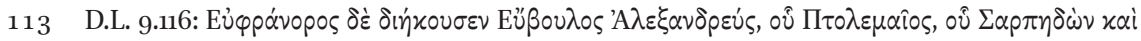

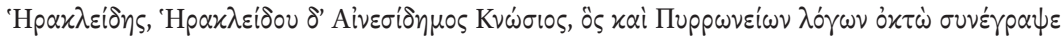

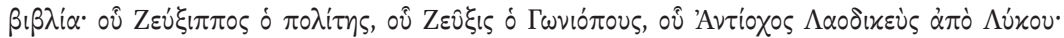

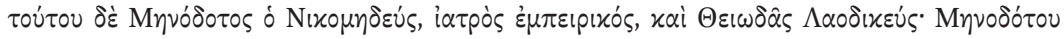

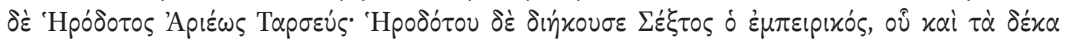

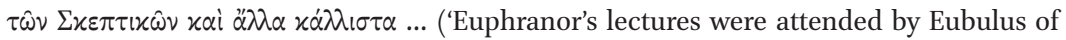
Alexandria, and his by Ptolemy, and his by Sarpedon and Heraclides, and Heraclides' by Aenesidemus of Cnossus, who also wrote 8 books of Pyrrhoneian arguments, and his by his fellow-citizen Zeuxippus, and his by Zeuxis the bent-footed, and his by Antiochus from Laodicea on the Lycus; and his were heard by Menodotus of Nicomedia, the empiricist doctor, and Theiodas of Laodicea; and Menodotus' were heard by Herodotus the son of Areus from Tarsus; and Herodotus' by Sextus the empiricist, who wrote the 10 books of Sceptical enquiries and other excellent works ...'), cf. Fernoux 2004, 490.

114 For good accounts see Stadter 1980; Tonnet 1988; Bosworth 1988; Lalanne and Hostein 2014; Liotsakis 2019; Strazdins forthcoming.

115 Cf. Millar 1966. 
'Lectures of Epictetus', much of his writing emulated that of Xenophon, e.g. his Cynegeticus and the work for which he is now best known, the Anabasis of Alexander. In his later years, partly spent in Athens where he was a citizen and held the archonship in AD 145/146, he wrote a history of Bithynia, still known to Photius and probably the source of some of our knowledge of Bithynian intellectuals. ${ }^{116}$

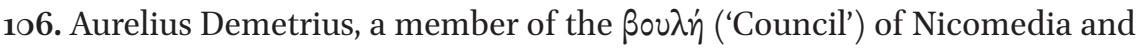

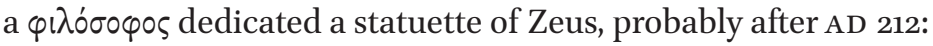

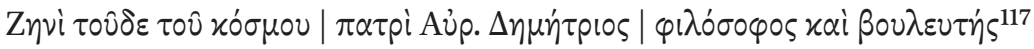

To Zeus, father of this universe, Aurelius Demetrius, philosopher and councillor (dedicated this)

Rhetors and Sophists

107. P. Aelius Samius Isocrates was buried at Ostia by his freedman Aelius Musicus:

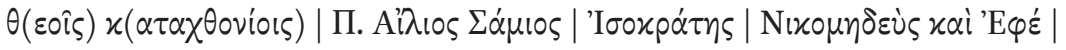

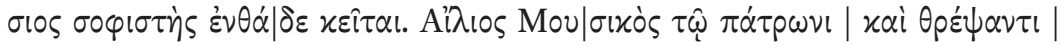
$\mu \nu \eta \dot{\mu} \mu \bar{s} \chi_{\alpha \dot{\alpha} \rho \nu .118}$

To the underworld gods. Publius Aelius Samius Isocrates, citizen of Nicomedia and Ephesus, sophist, lies here. Aelius Musicus (erected this) for his patronus who reared him, to commemorate him.

This seems to be a man called Samius, born in Nicomedia, but then acquiring citizenship at Ephesus, perhaps because he was active there as a sophist, and also Roman citizenship from Hadrian. The name Isocrates may have been taken or given as a compliment to his oratorical skills. Like Aristides in AD 144 Samius may have set off to Rome to climb higher on the sophistic ladder, but instead died in mid-career at Ostia.

116 See Merkelbach 1985 .

117 Şahin and Sayer 1982, 43 no. 1, Fernoux 2004, 492.

118 Ed.pr. Paribeni, NSc 5/6 1944/5, 79-8o, cf. Bull. 1949, no. 233, Puech 2002, no. 236. For the

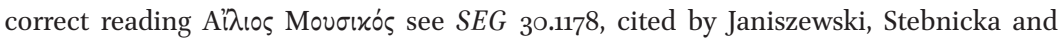

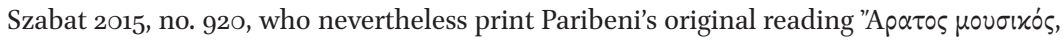
as did Fernoux 2004, 492. 
108. Basilicus, called a sophist by the Suda, registering technical works of rhetoric, ${ }^{119}$ taught Apsines in Nicomedia, ${ }^{120}$ presumably late in the second $\mathrm{c}$. Patillon argues that part of Ps.-Aristides Rhetorica is by Basilicus. ${ }^{121}$

109. P. Aelius Cleisthenes, who died aged 28 in Athens at some date in the second century after $\mathrm{AD} 117$, is termed rhetor in his brief epitaph. ${ }^{122}$

110. Quirinus is the only Bithynian given a Life by Philostratus. ${ }^{123}$ His teachers included Hadrianus of Tyre, who may have taught in Ephesus, ${ }^{124}$ and certainly held the imperial chair of rhetoric in Athens (from around AD 176) followed by that in Rome. Quirinus could have been Hadrianus' pupil in Ephesus or Athens, perhaps in the early or late 17os; less probably in Rome, but as P. Aelius Samius Isocrates (above no. 107) and other cases show, travel to Rome for cultural advancement was not unusual. Quirinus was appointed to the important post of advocatus fisci, probably, given his place in Philostratus' sequence of sophists, by Septimius Severus. Philostratus commends his restraint and probity, insisting that after eschewing exploitation of his powerful office he returned home poor, like the fifth-century Athenian Aristides, and was buried in Nicomedia. ${ }^{125}$

Scholars, grammatikoi, philologoi

111. The grammaticus Asclepiodotus visited Egypt and recorded his awe at the Syringes in Egyptian Thebes:

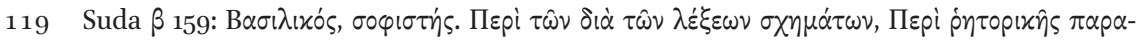
$\sigma$ figures of diction; On rhetorical preparation or On Practising; On paraphrase; and some

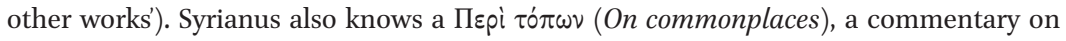

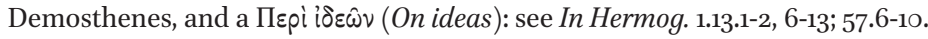

120 Suda s.v. Apsines $\alpha$ 4735.

121 Patillon 2002, xii-xv.

$122 I G \mathrm{ii}^{2} 10007$, inscribed on a funerary urn; surely different from the P. Aelius Cleisthenes commemorated in the stone epitaph published by Reynolds 1997, no. 5 a.

123 Philostr. VS 2.29, cf. Suda $x$ 2765; Fernoux 2004, 425-426; Janiszewski, Stebnicka and Szabat 2015, no. 601.

124 Cf. Hadrianus' poem honouring Claudius Severus, $I K 15$ no. 1539, on which see Keil 1953 and Jones 2002, 111-114. Page 1981, 566-568, following Groag, mistakenly took the poet to be the emperor Hadrian. For an important discussion of Hadrianus see Puech 2002, no. 128.

125 Bowersock 1969, 22 n. 1 proposed to emend Kupivas (found once in Philostratus' manu-

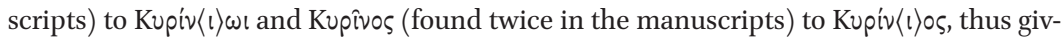
ing the nomen Quirinius, for which he compared IGRom. iii 810, honouring at Pamphylian Side Quirinia Patra, wife of Bryonianus Lollianus (for whom see IGRom. iii 811). We now know more about the nexus of families in southern Anatolia to which Quirinia Patra belonged (cf. PIR ${ }^{2}$ Q52-54) and nothing so far corroborates any connection with the Bithynian sophist. 


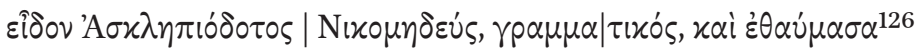

I, Asclepiodotus of Nicomedia, a grammaticus, beheld and felt wonder

\section{Visitors}

112. As from Nicaea (above no. 9o), so too from Nicomedia an epigram by Diodorus of Sardis (for a bridegroom, Hipparchus, who died at 24) passed into the Anthology. ${ }^{127}$ Like Diodorus' epigram for Achaeus it does not prove a visit, but Diodorus' links with Asia Minor make it not unlikely.

113. Late in the second century Nicomedia gave the status of bouleutes ('coun-

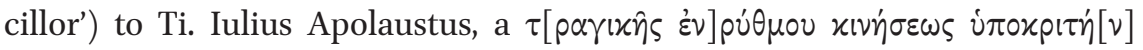
('performer of tragic rhythmic movement', i.e. pantomime): presumably he had performed impressively on a visit. ${ }^{128}$

\section{Prusa}

\section{Doctors}

121. C. Calpurnius Asclepiades' career is outlined by his grave inscription near Capua. Born on 13 March AD 87, the same day as his wife (whose nomen is inscribed as Veronia, but Verania is a possible correction $)^{129}$ he obtained Roman citizenship for his parents, himself and his four brothers; he lived for 51 years with his wife until his death, aged 70, in AD 157; and his professional skill and general integrity led to his approval by viri clarissimi and (it is implied) his appointment as an assessor to Roman magistrates, both in Asia and in other provinces, and as a supervisor of votes cast by jurors. His citizenship was

\footnotetext{
126 Baillet 1920-1926, no. 1739 .

$127 \quad A P 7.627=$ GVI $1472=$ Gow-Page 1968, Diodorus vi.

128 Delph. 3(1), 551, cf. Robert 1930, 654-664.

129 ILS 7789 = CIL xi 3943: C. Calpurnius Asclaepiades, Prusa ad Olympum, medicus | parentibus et sibi et fratribus civitates VII a Traiano divo | impetravit, natus III non. Mart. Domitiano XIII cos, eadem die quo uxor eius Veronia Chelidon, cum qua vixit annis LI $\mid$ studiorum et morum causa probatus a viris clarissimis, adsedit magistratibus populi Romani ita ut in aliis et in Asia provincia, custodiar (um) | [tabellar.?] in urna iudicum.Vixit annis $L X X$ ('C. Calpurnius Asclepiades, from Prusa by Olympus, a doctor, who successfully requested seven Roman citizenships from the divine Trajan for his parents, for himself and for his brothers; born $5^{\text {th }}$ March in the 13th consulate of Domitian, on the same day as his wife Veronia Chelidon, with whom he lived for 51 years; and thanks to his education and character he received the approval of the most eminent men, and sat as an adviser to magistrates of the Roman people both in Asia and in other provinces; he was supervisor of the votes of jurors and lived 70 years'). For the attractions of correcting to Verania see Bowie 2014, 40 with n. 31 .
} 
presumably obtained thanks to the intervention of a Calpurnius, perhaps after he had married a woman who was already a citizen. ${ }^{130}$

122. Marcus, son of Octavius, honoured by the demos of Prusa, was a doctor who stayed at home and died much younger than Asclepiades:

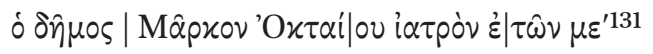

The people (honoured) Marcus, son of Octavius, a doctor, who lived 45 years

\section{Mime Writers and Performers}

122a. Philistion is allocated to Prusa (as well as to Nicaea or Sardes), see above no. 73 .

\section{Philosophers ${ }^{132}$}

123. (T. Flavius?) Dio Cocceianus (known since late antiquity as 'Dio Chrysostom'), probably owed his cognomen Cocceianus to the acquisition of Roman citizenship with Nerva's support in his consulate of AD 71. He is represented by 78 surviving prose 'orations'-sophistic, political and philosophical. ${ }^{133}$ Whether or not he was initially a sophist who was 'converted' to philosophy (Synesius' pattern, accepted by many moderns), perhaps by the Stoic Musonius, he seems certainly to have been banished from Bithynia and Italy by Domitian, and to owe his return in AD 96/97 to Nerva's friendship. Four orations on kingship purport to be for the benefit of Trajan, but whether any of these was delivered in his presence, or whether Dio (as Philostratus has it) ${ }^{134}$

130 This is not the only Asclepiades known from Prusa: cf. the magistratus ( $\pi p \omega \hat{\omega} \tau \circ \varsigma$ äp $\chi \omega \nu$, see Sherwin-White ad loc.) at Prusa in AD 110-111, Plin. Ep. 10.81.1 (thought by Sherwin-White to be older than our C. Calpurnius, probably rightly: but a member of the elite might perhaps be $\alpha p \chi \omega \nu$ at 23 or 24, despite the rules, for which see Ameling 1984).

131 IK 39 no. 29 (first or second century AD).

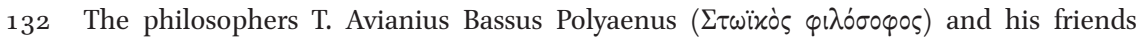
Avianius Apollonius (IK 39 no. 18) and P. Avianius Valerius Lysimachi f. (IK 39 no. 17), attested by inscriptions found in the wall at Prusa, are from nearby Mysian Hadriani ad Olympum, Şahin 1977, 257-258.

133 Good general accounts are von Arnim 1898; Desideri 1978 and 1991; Jones 1978; Swain (ed.) 2000; a review of scholarship to date by Harris 1991. On Dio's 'conversion' see especially Moles 1982; contra Sidebottom 2009; on the kingship orations especially Moles 1983 and Sidebottom 1991; good commentary on Orations 7, 12 and 36 by Russell 1992. On Dio's exploitation of Greek myth see Gangloff 20o6; for recent work Nesselrath and Amato 2009; Amato et al. 2016, and for new evidence on Dio as a landowner Ma 2019.

134 Philostr. VS 1.7.488. 
rode in his carriage in a triumph in Rome, can be questioned. Several speeches show Dio seeking to mitigate rivalry between Bithynian cities and embattled in the local politics of Prusa, as he is also found in Pliny's Letters of AD 110/111. ${ }^{135}$ Others, not all certainly Trajanic, address problems in other cities of the Greek East—Celaenae, Tarsus, ${ }^{136}$ Rhodes and Alexandria.

124. Flavius Archippus, whose praenomen was presumably Titus, secured the friendship of Domitian after AD 81, and emerges from Pliny's letters as a philosopher teaching in Prusa and attempting to benefit from the immunities for teachers and other professionals introduced by Vespasian - this despite conviction for a serious offence (he was damnatus ad metalla, 'condemned to the mines') around AD 79/80.137

\section{Rhetors}

125. L. Egnatius Victor Lollianus, honoured as rhetor at Athens, ${ }^{138}$ as proconsul

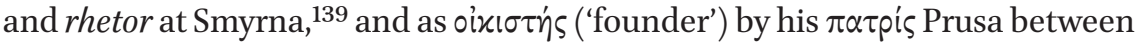
AD 225 and 242 when he was legatus of Bithynia-Pontus. ${ }^{140} \mathrm{He}$ rose to be proconsul Asiae and praefectus urbi. ${ }^{141}$

126. Cornutus was honoured by Firmus, apparently his pupil, to whom he probably taught rhetoric, but perhaps merely grammatike:

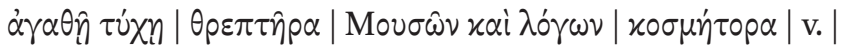

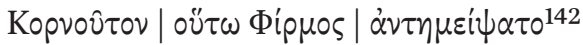

With good fortune. A nurse of the Muses and orderer of words

Cornutus was requited with this (monument) by Firmus

\section{A Teacher of Stenography}

127. Ti. Claudius Onesimus:

\footnotetext{
135 Plin. Ep. 10.81-82.

136 Editions of Orr. 33-35 with commentary, Bost-Pouderon 2006 and (with Or. 36) 2011. For the enigmatic first Tarsian (Or. 33) see Hawkins 2014.

137 Plin. Ep. 10.58-6o, PIR² F216, cf. Fernoux 2004, 494.

$138 \quad I G \mathrm{ii}^{2} 4217$.

$139 I K 23$ no. 635 .

$140 I K 39$ no. 12.

141 For the many other inscriptions and references to discussions of his senatorial career see PIR ${ }^{2}$ E36; Puech 2002, 330-336; Janiszewski, Stebnicka and Szabat 2015, no. 629.

$142 I K 39$ no. 53 (third or fourth century AD); Puech 2002, no. 70 (noting that lettering supports a late date); Janiszewski, Stebnicka, and Szabat 2015, no. 591.
} 


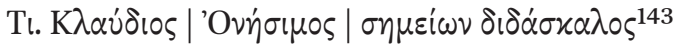

Tiberius Claudius Onesimus, a teacher of signs

A Teacher of Unnamed Discipline

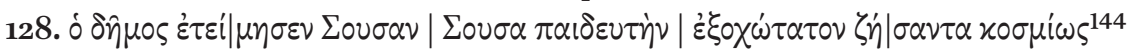

The people honoured Susas the son of Susas, a most outstanding teacher, who had lived decorously

\section{Prusias ad Hypium}

\section{Philosophers}

131. In Plutarch's Quaestiones convivales a Stoic Philippus is identified as from Prusias. ${ }^{145}$

\section{Rhetors}

Epitherses Aemilianus, chiefly associated with Nicaea, may have started life in Prusias, see above no. 84 .

\section{Students of Rhetoric}

132. Cornutus, who died in Athens:

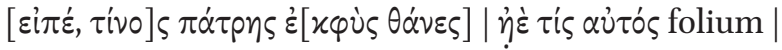

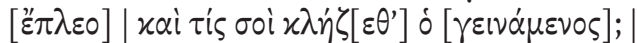

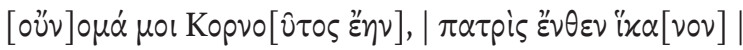

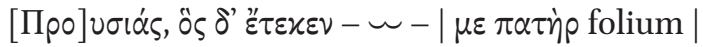

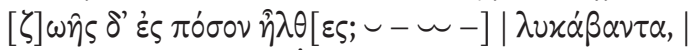

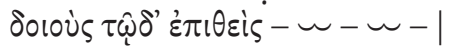

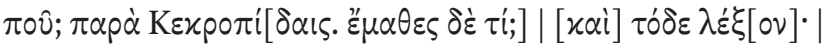

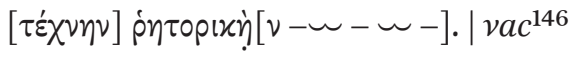

$143 I K 39$ no. 1043 (first or early second century AD). For this sense of $\sigma \eta \mu \varepsilon i \alpha$ cf. LSJ II 5.

$144 I K 39$ no. 1009 (first or second century AD).

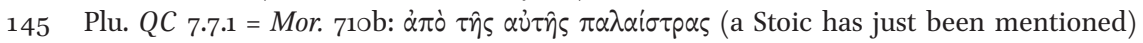

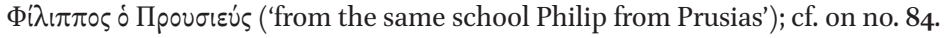

$146 I K{ }_{27} \mathrm{~T}_{15}=I G \mathrm{ii}^{2} 10118=$ GVI 1872, cf. Robert 1980, 78 n. 48o; Puech 2002, no. 274. This text seems to be from the second century, which excludes identification (suggested by an anonymous reviewer) of this Cornutus with no. 126, who seems to belong to the third or fourth century and is in any case from Prusa, not Prusias. 
'Tell me, from what country are you, who died, or who you were yourself, and what was the name of your father?'

'My name was Cornutus, the country I came from was Prusias. And the father who begat me was $[-\sim-]$ '.

'And how much life did you reach?'

'The ... year, with two months more'.

'[And you ended it] where?'

'Among the descendants of Cecrops.'

'And what did you study? Tell this too'.

'[The art] of rhetoric ...)'

133. Calpurnius Calpurnianus, who died in Ephesus (for his name cf. the Prusan Calpurnius Asclepiades no. 121):

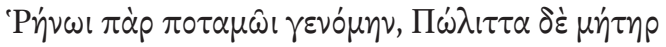

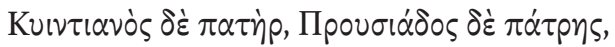

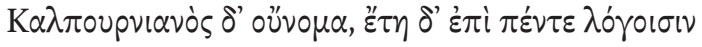

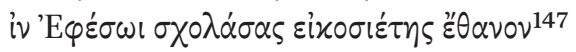

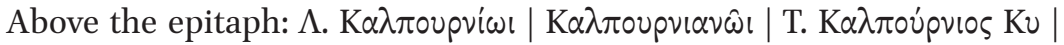

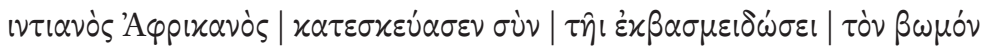

'I was born by the river Rhine, Politta was my mother,

Quintianus my father, and I was from the city of Prusias, and my name was Calpurnianus, and after five years

studying oratory in Ephesus I died aged twenty'.

Above the epitaph: For L. Calpurnius Calpurnianus T. Calpurnius Quintianus Africanus built the altar with its steps

\section{Visiting Performers}

134. Ti. Claudius Philoxenus, an Athenian tragoedus, died in Prusias:

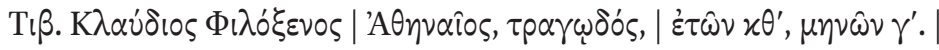

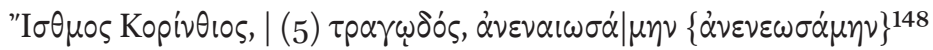

\footnotetext{
$147 I K{ }_{27} \mathrm{~T}_{14}=I K{ }_{15}$ no. $1627=I B M 627=$ GVI 1081, cf. Robert 1980, 79 n. 488; Puech 2002, no. 273 .

$148 I K 27$ no. $97=S E G$ 20.30, Stefanis 1988, no. 2540: first or second century AD.
} 
Tiberius Claudius Philoxenus, citizen of Athens, tragic performer, 29 years 3 months.

I Isthmus, citizen of Corinth, tragic performer, restored (his tomb)

135. Philoxenus' tomb was restored by another visiting tragoedus from Corinth, with the catchy name Isthmus, ${ }^{149}$ see no. 134 above.

\section{Unknown City}

\section{Sophistic Performer?}

140. An Aufria honoured at Delphi is probably Bithynian: the decree honouring her for her paideia and rhetorical performances during the Pythia (of AD 119 or

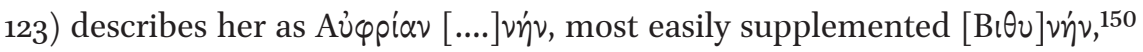
and the rare nomen appears in Greek epigraphy only in Bithynia: $I K 3_{2}$ no. $5^{2}$ (Aufria, not in $L G P N$ ), $I K 39$ no. 98 (Aufrianus).

\section{Writer (? Anthologist?)}

141. Damophilus of Bithynia, noted by the Suda as raised by Julianus, consul in Marcus' reign, ${ }^{151}$ dedicated one of his many works to a Lollius Maximus. ${ }^{152}$ Julian Misopogon $29.18=358 \mathrm{c}-\mathrm{d}$ mentions an anthology: $\Delta \alpha \mu \circ \varphi i \lambda \omega \tau \hat{\mathrm{B}} \mathrm{B} \theta \mathrm{\theta} v \hat{\omega}$

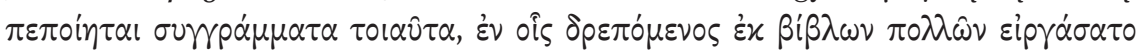

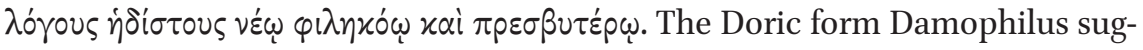
gests his origin to be the Megarian colony Chaldedon, where Doric forms are found at least as late as the Augustan period ( $I K 20$ no. 19, cf. no. $11=$ Sokolowski 1955 , no. 5). Perhaps his entry to elevated circles in Rome was eased by Marcus' philosophy teacher Apollonius of Chalcedon (above no. 24), though his 'raising' by Didius Iulianus could be as late as the latter's proconsulate of Bithynia, i.e. post-175 (SHA Didius Iulianus 2.3).

\footnotetext{
149 Stefanis 1988, no. 129 o.

15 Delph. 3(4), 79; Puech 2002 no. 53; Janiszewski, Stebnicka and Szabat 2015, no. 199.

151 Probably Didius Iulianus, cos. 175, briefly emperor in AD 193.

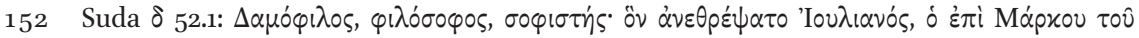

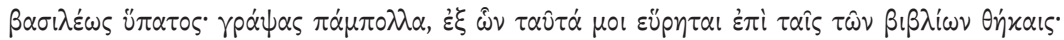

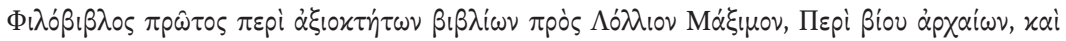

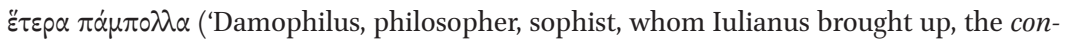
sul under the emperor Marcus. He wrote numerous works, of which I have found the following in libraries: Philobiblos (Book 1), on books worth acquiring, dedicated to Lollius Maximus; On the lifestyle of the ancients; and many other works'). For further references see Janiszewski, Stebnicka and Szabat 2015, 84 no. 246.
} 
Astrologer

\section{Astronomer}

Doctor

Acilius Theodorus \&

Herophilus

Asclepiades

a relative Theodorus

$(1 / 2 c)$

Athenocles

(late 2c/very early 1c BC)

Empeiria

\section{Historian}

Philosopher 'Lasthenes'

(c. 7O)
Iulius Nicetes

(Hadrianic)
Apollonius

(mid 2c)

Dionysius

(dialecticus)

(4C BC)

Xenocrates

(4c BC)

Performer

Poet

Maximus 


\begin{tabular}{|c|c|c|c|c|}
\hline $\begin{array}{l}\text { Crateia- } \\
\text { Flaviopolis }\end{array}$ & Nicaea & Nicomedia & Prusa & $\begin{array}{l}\text { Prusias ad } \\
\text { Hypium }\end{array}$ \\
\hline
\end{tabular}

Antigonus

(Hadrianic)

Protagoras early

(2c BC)

Hipparchus (mid/

late $2 \mathrm{c} \mathrm{BC}$ )

Theodosius and sons

Antigonus
Paulus
Pisistratus
Hedys

Cassius Dio (c. 164

-post 229)

Menecrates

Philippus

(Plu. De def. or.)

Apollo(s)

(1C BC)

Asclepiodotus 1

(late 2c BC)

Asclepiodotus 2

Marcus Atinianus

Bataces

(mid-2c BC)

Lycander

Lycon

Mentor

(mid-2c BC)

Nicias

Philistion?

Apollonides (1C AD)

Parthenius mid (1C BC)
Ti. Claudius Oclatius

Dionysius

(mid/late 1c?)
Flavius Atticus

(late 1c)

Menodotus (mid

2c AD)

Q. Aelius Archelaus d.

Rome

L. Flavius Arrianus

(c.86-16o)
Aur. Demetrius

$(2 / 3 \mathrm{c})$

L. Flavius Arrianus

(c.86-c.15o)
C. Calpurnius

Asclepiades

(87-157)

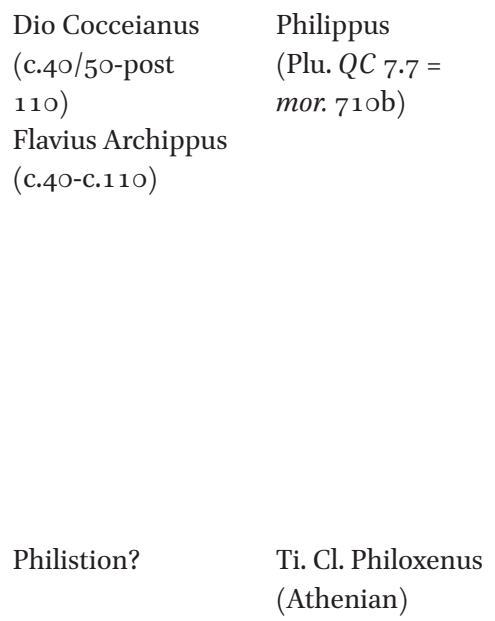

Dio Cocceianus Philippus

(c.40/5o-post (Plu. QC $7 \cdot 7=$

110) mor. $71 \mathrm{ob})$

Flavius Archippus

(c.40-c.110)

Philistion?

Ti. Cl. Philoxenus

(Athenian) 


\begin{tabular}{|c|c|c|c|}
\hline Rhetor & $\begin{array}{l}\text { Cleochares/ } \\
\text { Cleophanes } \\
\text { (3с BC) }\end{array}$ & Theodorus Attali f. & $\begin{array}{l}\text { Thrasymachus } \\
\text { (late } 5 \mathrm{c} \mathrm{BC} \text { ) }\end{array}$ \\
\hline
\end{tabular}

Scholar/

Grammaticus

Asclepiades s. of

Diotimus

(1с BC)

Student

Nonius?

Teacher

Teacher

\section{Visitors}


Crateia-

Flaviopolis
Nicomedia

Nicaea

Epitherses Aemilianus

Arche

[polis] or Arche[moros]

(2c)

P. Catillius Macer

(Hadrianic)

Euandros s. of Demonis

Longinus

Sacerdos?

(Hadrianic)

Apollonides early (1c)

Diogenes Laertius

(early 3c/late 2c)

Diophanes (pre-Plin.

Nat.)

Heliodorus

Hierax

Isigonus

(pre-Plin. Nat.)

Parthenius (mid

1c BC)

Sporus

(3c)

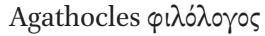

(d. Smyrna)
P. Aelius Samius

Isocrates

(post 117)

P. Aelius Cleisthenes

Basilicus

Quirinus

(c.150-210)

Asclepiodotus

Asclepiodotus
Prusa

Dio Cocceianus

(c.40/5o-post

110)

L. Egnatius Victor

Lollianus (3c)

Cornutus
Prusias ad

Hypium
Epitherses

Aemilianus (1c)

(before moving to

Nicaea)
Cornutus d.

Athens (2-3c)

Calpurnius

Calpurnianus (d.

Ephesus? 1c)

Ignotus Basileus [teacher of mathematics]

Ti. Cl. Onesimus

(stenography)

Asclepiodotus

(grammaticus)

Diodorus of Sardis? $\quad$ Diodorus of Sardis? $\quad$ poet of $A P 9.676 \quad$ Isthmus (Corinth) 


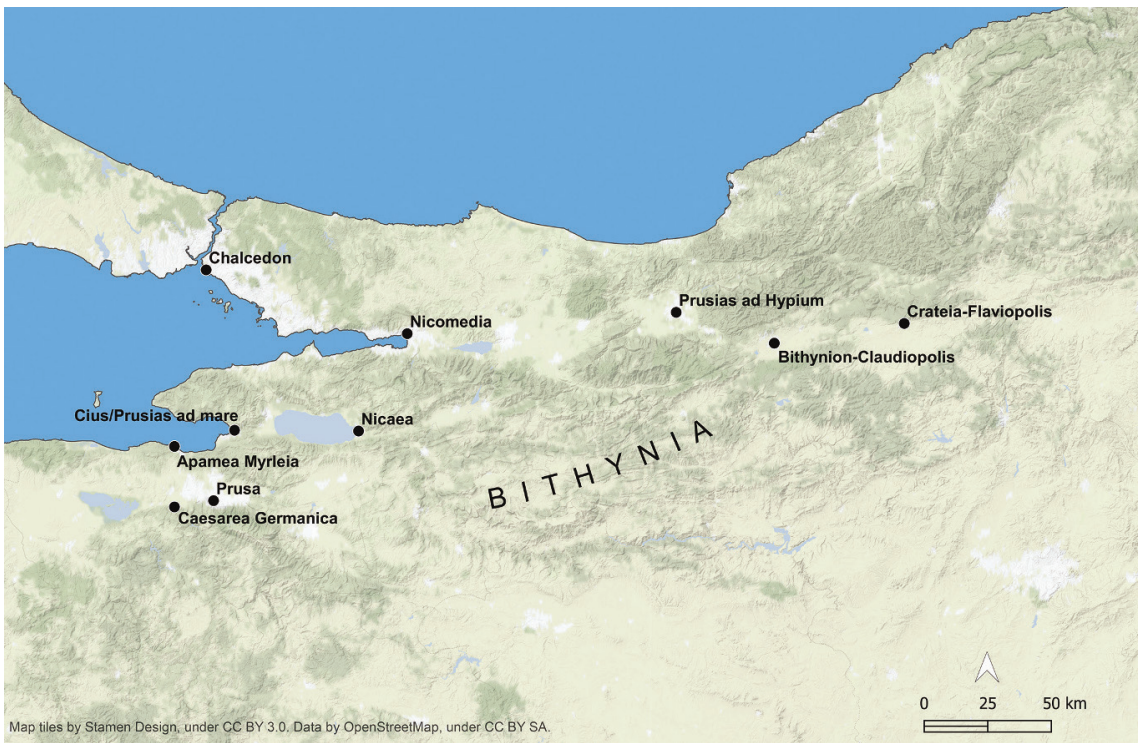

MAP 1 Greek cities in Bithynia, by Anna Kouremenos

\section{Bibliography}

Amato, E., Bost-Pouderon, C., Grandjean, T., Thévenet, L., and Ventrella, G., eds. (2016). Dion de Pruse. L'homme, son œuvre et sa postérité. Actes du colloque Nantes, 21-23 mai 2015. Hildesheim.

Ameling, W. (1984). Das Archontat in Bithynien. EA 3, pp. 19-31.

von Arnim, H. (1898). Leben und Werke des Dion von Prusa. Berlin.

Baillet, J. (1920-1926). Inscriptions grecques et latines des tombeaux des rois ou Syringes à Thèbes. Cairo.

Bekker-Nielsen, T. (2008). Urban Life and Local Politics in Roman Bithynia. Aarhus.

Birley, A.R. (1997). Hadrian. The Restless Emperor. London.

Bost Pouderon, C. (2006). Dion Chrysostome, Trois discours aux villes (Orr. 33-35). Salerno.

Bost Pouderon, C. (2011). Dion Chrysostome, Premier Discours à Tarse (Or. XXXIII)Second Discours à Tarse (Or. XXXIV)—Discours à Célènes de Phrygie (Or. XXXV)— Discours borysthénitique (Or. XXXVI). Paris.

Bosworth, A.B. (1988). From Arrian to Alexander. Studies in Historical Interpretation. Oxford.

Bowersock, G.W. (1965a). Some Persons in Plutarch's Moralia. CQ 15, pp. 267-270.

Bowersock, G.W. (1965b). Augustus and the Greek World. Oxford.

Bowersock, G.W. (1969). Greek Sophists in the Roman Empire. Oxford. 
Bowie, E.L., and Elsner, J., eds. (2009). Philostratus. Cambridge.

Bowie, E.L. (2012). Luxury Cruisers? Philip's Epigrammatists between Greece and Rome. Aevum Antiquum 8, pp. 223-258.

Bowie, E.L. (2014). Greek Culture in Arrian's Bithynia. Ktèma 39, pp. 37-49 [= S. Lalanne and A. Hostein, eds., Le monde d'Arrien de Nicomédie].

Bowie, E.L. (2017). Philosophia and Philosophoi in Athenaeus. In: P. Vesperini, ed., Philosophari. Usages romains des savoirs grecs sous la République et sous l'Empire, Paris, pp. 431-465.

Bowie, E.L. (2021). Greek grammatici in the Roman Empire. In: A.-M. Favreau-Linder, S. Lalanne, and J.-L. Vix, eds., Passeurs de culture, Turnhout, pp. 17-32.

Cichorius, C. (1922). Römische Studien. Leipzig.

Corsten, T. (1987). Die Inschriften von Apamea (Bithynien) und Pylai [= IK 32$]$. Bonn.

Corsten, T. (1990). Caesarea Germanice. EA 15, pp. 19-48.

Cramer, F.H. (1954). Astrology in Roman Law and Politics. Philadelphia.

Daux, G. (1935). Craton, Eumène II et Attale II. $\mathrm{BCH}$ 59, pp. 210-230.

Desideri, P. (1978). Dione di Prusa. Un intellettuale greco nell'Impero romano. Messina/ Florence.

Desideri, P. (1991). Dione di Prusa fra ellenismo e romanità. ANRW II.33.5, pp. 3882-3902.

Fechner, D. (1986). Untersuchungen zu Cassius Dios Sicht der Römischen Republik. Hildesheim/New York.

Fernoux, H.-L. (2004). Notables et élites des cités de Bithynie aux époques hellénistique et romaine. III e siècle av.J.-C.-III ${ }^{e}$ siècle ap.J.-C.. Essai d'histoire sociale. Lyon.

Ferrary, J.-L. (2005). Les mémoriaux de délégations du sanctuaire oraculaire de Claros et leur chronologie. CRAI 149, pp. 719-765.

Ferrary, J.-L. (2014). Les mémoriaux de délégations du sanctuaire oraculaire de Claros, d'après la documentation conservée dans le Fonds Louis Robert. (2 vols). Paris.

Ferrua, A. (1966). Antiche iscrizioni inedite di Roma. Epigraphica 28, pp. 18-49.

Frija, G. (2010). Prosopographie des prêtres du culte impérial dans les cités de la province romaine d'Asie. http://www.pretres-civiques.org/.

Frija, G. (2012). Les prêtres des empereurs. Le culte impérial civique dans la province romaine d'Asie. Rennes.

Gangloff, A. (2006). Dion Chrysostome et les mythes. Hellénisme, communication et philosophie politique. Paris.

Geiger, J. (2014). Hellenism in the East. Studies on Greek Intellectuals in Palestine. Stuttgart.

Gow, A.S.F., and Page, D.L. (1968). The Greek Anthology. The Garland of Philip and Some Contemporary Epigrams. (2 vols). Cambridge.

Gowing, A. (1992). The Triumviral Narratives of Appian and Cassius Dio. Ann Arbor.

Harris, B.F. (1991). Dio of Prusa. ANRW II 33.5, pp. 3853-388.

Hawkins, T. (2014). Iambic Poetics in the Roman Empire. Cambridge. 
Imhoof-Blumer, F. (1901-19o2). Kleinasiatische Münzen. Vienna.

Janiszewski, P., Stebnicka, K., and Szabat, E. (2015). Prosopography of Greek Rhetors and Sophists of the Roman Empire. Oxford.

Jones, C.P. (1978). The Roman World of Dio Chrysostom. Oxford.

Jones, C.P. (2002). Epigraphica. ZPE 139, pp. 108-116.

Keil, J. (1953). Vertreter der zweiten Sophistik in Ephesos. JöAI 4O, pp. 5-26.

Kennedy, G. (1963). The Art of Persuasion in Greece. Princeton.

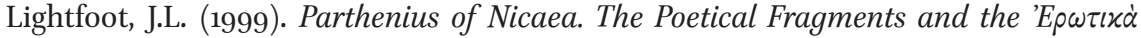

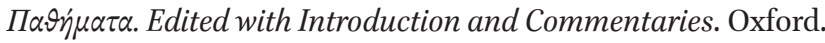

Lightfoot, J. (2017). Hipparchus' Didactic Journey. GRBS 57, pp. 935-967.

Liotsakis, V. (2019). Alexander the Great in Arrian's Anabasis. Berlin/New York.

Lucas, G. (1992). La Tripolis de Perrhébie et ses confins, organisation territoriale et corpus épigraphique. In: I. Blum, ed., Topographie antique et géographie historique en pays grec, Paris, pp. 93-137.

Ma, J. (2019). Dio Chrysostom's Estate. EA 52, pp. 133-138.

Madsen, J.M. (2009). Eager to Be Roman. London.

Madsen, J.M. (2019). Cassius Dio. London.

Magie, D. (1950). Roman Rule in Asia Minor. Princeton.

Manuwald, B. (1979). Cassius Dio und Augustus. Philologische Untersuchungen zu den Büchern 45-56 des dionischen Geschichtswerkes. Wiesbaden.

Marek, C. (2003). Pontus et Bithynia. Die römischen Provinzen im Norden Kleinasiens. Mainz.

Mejer, J. (1978). Diogenes Laertius and his Hellenistic Background. Wiesbaden.

Merkelbach, R. (1984). Trostdekret über den Tod eines Studenten der Rhetorik aus Claudiopolis. EA 3, pp. 137-140.

Merkelbach, R. (1985). 'Nikaia die Rankenreiche (E $\Lambda \mathrm{IK} \Omega \mathrm{PH})$ '. Ein übersehenes Fragment aus Arrians Bithyniaka. EA 5, pp. 1-3.

Merkelbach, R. (1987). Nikaia in der römischen Kaiserzeit. Opladen.

Merkelbach, R., and Stauber, R. (2001). Steinepigramme aus dem griechischen Osten, Vol. 2. Bonn.

Millar, F.G.B. (1964). A Study of Cassius Dio. Oxford.

Millar, F.G.B. (1966). Epictetus and the Imperial Court. JRS 56, pp. 141-148.

Miranda, E. (1992-1993), Commodeia. Scienze dell'antichità 6-7, pp. 66-88.

Mitchell, S. (1993). Anatolia. Land, Men, and Gods in Asia Minor. Oxford.

Moles, J.L. (1978). The Career and Conversion of Dio Chrysostom.JHS 98, pp. 79-100.

Moles, J.L. (1983). The Date and Purpose of the Fourth Kingship Oration of Dio Chrysostom. ClAnt 2, pp. 251-278.

Mueller, C., and Hasenohr, C. (2002). Les Italiens dans le monde grec. II ${ }^{e}$ siècle av. J.-C.-I ${ }^{\text {er }}$ siècle ap.J.-C.. Circulation, activités, intégration. Actes de la table ronde, École normale supérieur, Paris, 14-16 mai 1998. Paris. 
Nesselrath, H.-G., and Amato, E. (2009). Der Philosoph und sein Bild. Tübingen.

Neugebauer, O. (1975). A History of Ancient Mathematical Astronomy. Berlin/New York. Nisbet, G. (2003). Greek Epigram in the Roman Empire. Martial's Forgotten Rivals. Oxford.

Nutton, V. (1977). 'Archiatri' and the Medical Profession in Antiquity. PBSR 45, pp. 191226 [repr. with additions in Nutton 1988].

Nutton, V. (1988). From Democedes to Harvey. Studies in the History of Medicine. London. Page, D.L. (1981). Further Greek Epigrams. Cambridge.

Patillon, M. (2002). Ps.-Aelius Aristide, Arts rhétoriques. Paris.

Petzl, G., and Schwertheim, E. (2008). Hadrian und die Dionysischen Künstler. Drei in Alexandria Troas neugefundene Briefe des Kaisers an die Künstler-Vereinigung. Bonn.

Puech, B. (2002). Orateurs et sophistes grecs dans les inscriptions d'époque impériale. Avec préface de L. Pernot. Paris.

Radt, S. (2002-2011). Strabonis Geographika. Mit Übersetzung und Kommentar. (10 vols). Göttingen.

Rawson, E.D. (1982). The Life and Death of Asclepiades of Bithynia. CQ 32, pp. 358-370.

Reynolds, J. (1997). Five Smyrnaean Inscriptions Rescued from the English Channel. EA 29, pp. 129-133.

Robert, L. (1930). Pantomimen im griechischen Orient. Hermes 65, pp. 106-122 [= Opera Minora Selecta 1, pp. 654-670].

Robert, L. (1980). A travers l'Asie Mineure. Paris.

Rohde, E. (1873). Aelius Promotus, RhM 28, pp. 264-9o.

Russell, D.A. (1992). Dio Chrysostom, Orations VII, XII, XXXVI. Cambridge.

Şahin, S. (1973/1974). Neufunde von antiken Inschriften in Nikomedeia (Izmit) und in der Umgebung der Stadt. Dissertation, Münster.

Şahin, S. (1977). Ein Stein aus Hadrianoi in Mysien in Bursa. ZPE 24, pp. 257-258.

Şahin, S. (1978). Bithynische Studien/Bithynia incelemeleri. Bonn.

Şahin, S., and Sayar, M.H. (1982). Fünf Inschriften aus dem Gebiet des Golfes von Nikomedeia. ZPE 47, pp. 43-50.

Schamp, J. (1987). Photius historien des lettres. La 'bibliothèque' et ses notices biographiques. Paris.

Sidebottom, H. (1991). Studies in Dio on Kingship. Dissertation, Oxford.

Sidebottom, H. (2009). Philostratus and the Symbolic Roles of the Sophist and Philosopher. In: E.L. Bowie and J. Elsner, eds., pp. 69-99.

Slater, W.J. (1972). Asklepiades and Historia. GRBS 13, pp. 317-333.

Sokolowski, F. (1955). Lois sacrées de l'Asie Mineure. Paris.

Sourvinou-Inwood, C. (2005). Hylas, the Nymphs, Dionysos and Others. Myth, Ritual, Ethnicity. Stockholm.

von Staden, H. (1989). Herophilus. The Art of Medicine in Early Alexandria. Edition, Translation and Essays. Cambridge. 
Stadter, P.A. (1980). Arrian of Nicomedeia. Chapel Hill, NC.

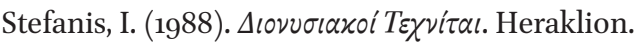

Strazdins, E. (forthc.). Fashioning the Future in Roman Greece. Memory, Monuments, Texts. Oxford.

Strobel, C. (2011). Studies in Atticistic Lexica of the Second and Third Centuries AD. Dissertation, Oxford.

Swain, S.C.R., ed. (200o). Dio Chrysostom. Politics, Letters and Philosophy. Oxford.

Tonnet, H. (1988). Recherches sur Arrien. Sa personnalité et ses écrits atticistes. Amsterdam.

Toomer, G.J., and Jones, A. (2012). Hipparchus (3). OCD, 4th ed., pp. 685-686. 